\title{
Petrological and geochemical characteristics of Paleoproterozoic ultramafic lamprophyres and carbonatites from the Chitrangi region, Mahakoshal supracrustal belt, central India
}

\author{
RAJESH K SRIVASTAVA \\ Centre of Advanced Study, Department of Geology, Banaras Hindu University, Varanasi 221 005, India. \\ e-mail: rajeshgeolbhu@yahoo.com
}

\begin{abstract}
A number of ENE-WSW trending Paleoproterozoic dykes and plugs of mafic, ultramafic, alkaline and carbonatite rocks intrude Mahakoshal supracrustal belt (MSB), which is a part of the Central Indian Tectonic Zone (CITZ). Best exposures of these intrusions are found in the eastern parts of the MSB, particularly in and around Chitrangi area. Many of these intrusions have greenschist facies mineral composition and show sharp contact with supracrustal rocks. However, igneous textures, such as porphyritic/glomeroporphyritic, are still preserved in the form of partly pseudomorphed olivines, phlogopites and pyroxenes. Striking feature observed in some ultramafic samples is the presence of melanite garnet and rounded or elliptical carbonate ocelli. The petrographic characteristics suggest occurrence of carbonate-rich ultramafic lamprophyres; close to aillikite composition. Coarse-grained carbonatites show hypidiomorphic texture and mostly composed of calcite with appreciable amount of silicate minerals like clinopyroxene, phlogopite and olivine (often pseudomorphed by calcite, amphibole and chlorite). It is difficult to establish any direct genetic relationship between carbonatite and ultramafic lamprophyre samples on the basis of their chemistry; they were likely derived from distinct parental melts. High Mg\# (up to 78), and high $\mathrm{Ni}$ and Cr contents (up to $~ 1700$ and $~ 1100$, respectively) and low HREE concentration in few ultramafic lamprophyre samples apparently suggest their derivation from a near-primary mantle-derived melts originated at great depths. Geochemistry and presence of carbonate ocellae in ultramafic lamprophyre samples suggest genesis of these silicate rocks and associated carbonatites through liquid immiscibility, however possibility of their derivation through vein-plus-wall-rock melting model cannot be ignored. A multi-stage veined mantle melting model is suitable in the latter case. It is suggested that early stages of rifting in the Mahakoshal region due to lithospheric thinning caused by possible plume activity provided suitable conditions for the genesis of ultramafic lamprophyre (possibly aillikitic) and carbonatitic melts which ultimately crystallized as dykes and plugs.
\end{abstract}

\section{Introduction}

Alkaline and carbonatitic igneous rocks in the Precambrian geological record, in comparison to Phanerozoic, are not very common and have been reported in few terrains only (Blichert-Toft et al. 1996). Blichert-Toft et al. (1996) stated few possible reasons for this:

- either they derive from very small volumes of melt and did not survive through time

Keywords. Paleoproterozoic; ultramafic lamprophyre; aillikite; carbonatite; geochemistry; genesis; Mahakoshal supracrustal belt; central India. 
- or thermodynamic conditions for the generation of such melts were not suitable

- or lower $\mathrm{CO}_{2}$ contents in the melting regions did not support the formation of silicaundersaturated magmas

- or the absence of metasomatized lower lithosphere prohibited the formation of rift-type magmas in general.

Although alkaline silicate rocks, such as melilitolites, ijolite, phonolite, syenite, lamprophyres, kimberlites, ultramafic-mafic rocks, etc., are commonly associated with carbonatites (Bell 1998; Bell et al. 1998; Woolley 2003; Tappe et al. 2011), many have questioned any direct genetic relationship between them (Harmer 1999; Gittins and Harmer 2003; Srivastava et al. 2005). The association of ultramafic lamprophyre with carbonatite is reported by many researchers (Blichert-Toft et al. 1996; Le Roex and Lanyon 1998; Woolley 2003; Vichi et al. 2005; Tappe et al. 2006); few of them

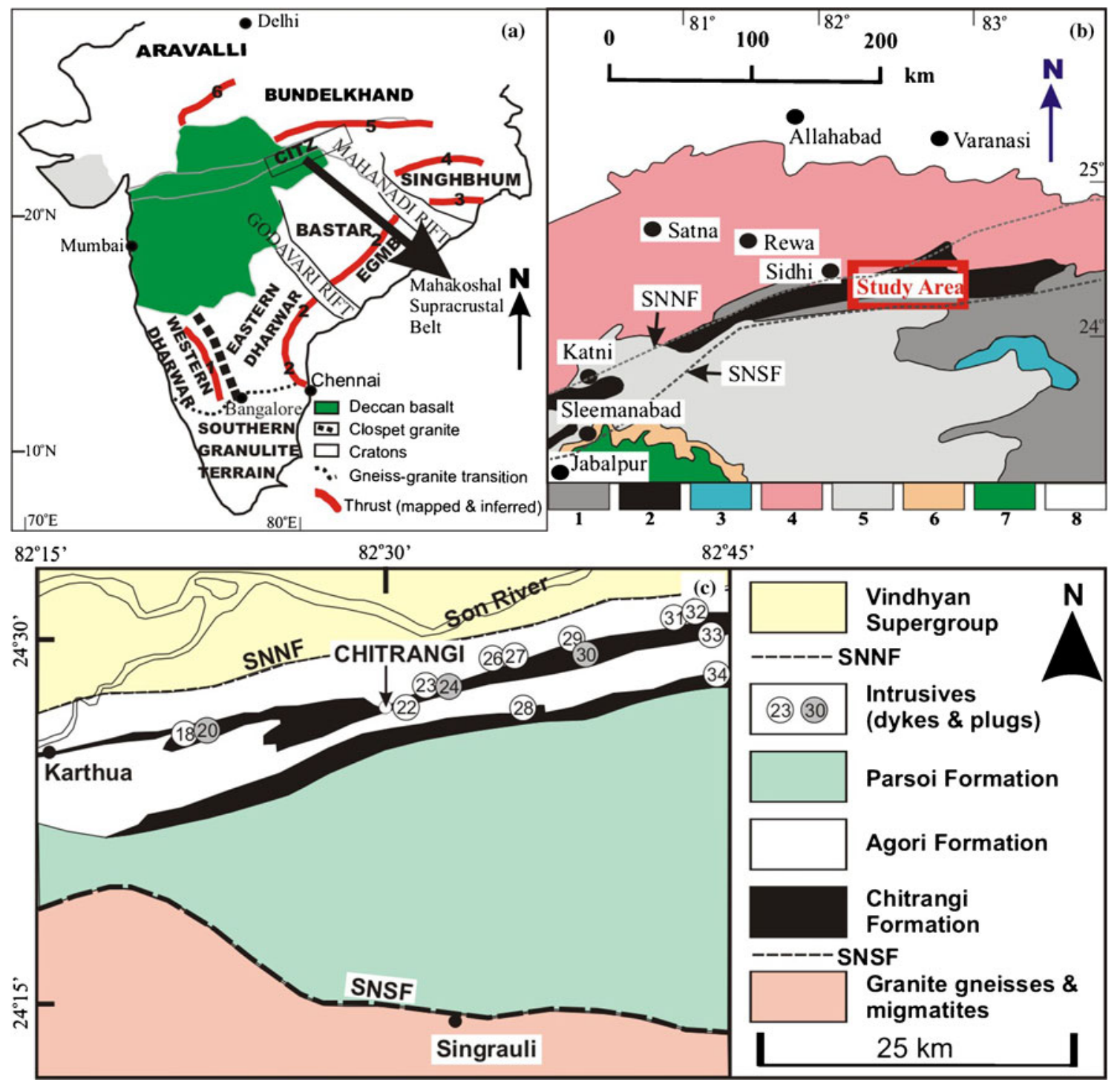

Figure 1. (a) Major cratons and structural features of India (after Naqvi and Rogers 1987). CITZ: Central Indian Tectonic Zone; EGMB: Eastern Ghats Mobile Belt. Major structural features are: 1. Small thrusts in western Dharwar craton, 2. Eastern Ghat front, 3. Sukinda, 4. Singhbhum, 5. Son Valley, and 6. Great Boundary fault. (b) Simplified geological map of a part of the northeastern portion of central India (modified from Roy et al. 2000). 1. Granitoids (gneisses, migmatites and granulites), 2. Palaeo- to Mesoproterozoic Mahakoshal supracrustal belt (MSB), 3. High-grade gneiss-supracrustal and medium grade metasedimetaries equivalent to Dongargarh Group, 4. Meso- to Neoproterozoic Vindhyan Supergroup, 5. Gondwana Supergroup, 6. Lameta Group, 7. Deccan basalts, and 8. Quaternary and Recent sediments. SNNF: SonNarmada North Fault; SNSF: Son-Narmada South Fault. (c) Generalized geological map of the Chitrangi region (the study area), Mahakoshal supracrustal belt, central India (modified after Jain et al. 1995a). Chitrangi Formation includes basic/ultrabasic extrusive rocks and minor intrusive rocks; Agori Formation incorporates phyllites with tuffs, BIF and dolomites with cherts and lenses of metabasalts; Parsoi Formation includes phyllites, quartzite, tuffs, etc.; and intrusives include dykes and plugs of ultramafic lamprophyres, carbonatites, mafic/ultramafic rocks, syenites, etc. 
are emplaced during Proterozoic. Such occurrences are generally confined to regions of lithospheric extension (Rock 1986; Tappe et al. 2005, 2006; Mitchell and Tappe 2010). It is well-known that ultramafic lamprophyres may contain appreciable amount (up to $\sim 40$ vol. $\%$ ) of carbonate, have low $\mathrm{SiO}_{2}$ contents, and therefore their association with carbonatite is common (Vichi et al. 2005; Tappe et al. 2006). Ultramafic lamprophyres are often found as dykes or plugs (Rock 1991). Although carbonatites, lamprophyres and other associated alkaline ultramafic silicate igneous rocks are volumetrically minor components of continental magmatism, their systematic studies provide valuable information on our understanding of deep melting events during the initial stages of continental rift development (cf. Tappe et al. 2006).

Tappe et al. (2005) reclassified ultramafic lamprophyres into three types; alnöite (essential groundmass melilite), aillikite (essential primary carbonate) and damtjernite (essential groundmass nepheline and/or alkali feldspar). These mineralogical characteristics clearly distinguish aillikite from alnöite and damtjernite, however some other criteria are required to distinguish aillikite from olivine lamproites, kimberlite and orangeite. Ultramafic lamprophyres can be distinguished from olivine lamproites by the occurrence of primary carbonates, and from kimberlites by the presence of groundmass clinopyroxene. Aillikites are characterized by primary groundmass carbonate and contain melanite/schorlomite or kimzeyite garnets, however if such garnet is absent in an ultramafic lamprophyre but is carbonate-bearing, it may be an aillikite, orangeite (former Group 2 kimberlite) or archetypal kimberlite. In such cases, discrimination must rely on differences in mineral composition (Tappe et al. 2005). However, there are some geochemical criteria to distinguish between ultramafic lamprophyre, kimberlite, orangeite and lamproite (Lefebvre et al. 2005). In many cases aillikites modally grade into carbonatites (Rock 1986; Mitchell et al. 1999; Tappe et al. 2005, 2006). Although aillikites sensu-stricto have not been reported from India, potassic intrusives with affinities to aillikites ( $\sim 117 \mathrm{Ma})$ have been reported from Jharia area, Singhbhum craton (cf. figure 1; Srivastava et al. 2009). Srivastava and Chalapathi Rao (2007) studied the Paleoproterozoic Mahakoshal greenstone belt of central India in Jungel Valley and reported the presence of a wide spectrum of undersaturated alkaline intrusive rocks comprising lamprophyres, highly carbonated rocks (carbonatites?) and ultrabasic rocks as intrusions into the Mahakoshal supracrustal belt. Mafic-ultramafic and alkaline intrusions within the Mahakoshal supracrustal belt have also been described by earlier researchers (Roy and Bandyopadhyay 1988, 1990; Jain et al. 1995a; Roy and Hanuma Prasad 2003; Srivastava and Chalapathi Rao 2007; Roy and Chakraborty 2008), however only few have presented petrography and geochemistry (major elements only) for the ones found in and around Chitrangi region (Jain et al. 1995a; Nair et al. 1995) (figure 1).

This work aims to petrologically and geochemically characterize a diverse suite of Paleoproterozoic carbonate-rich ultramafic lamprophyres (possibly aillikite) and define their possible petrogenetic association with carbonatites of the Chitrangi region, Mahakoshal supracrustal belt, central India. This work could help to understand the petrogenesis of these rocks by evaluating the nature of their parental melts and the processes involved in their magmatic and also the possible role of a mantle plume in their genesis. This study could also throw light on the possible emplacement of ultramafic lamprophyre in this region which indicates magmatic activity in an extensional tectonic environment (lithospheric thinning possibly caused by a plume) during Paleoproterozoic.

\section{Geological setting}

Central Indian Tectonic Zone (CITZ), bordered by Son-Narmada North Fault (SNNF) in the north and Son-Narmada South Fault (SNSF) in the south, is a major crustal and tectonic feature in peninsular India. The ENE-WSW trending CITZ is considered to have evolved during Proterozoic through polyphase tectonothermal events involving several cycles of volcanosedimentary deposition, deformation, metamorphism and magmatism (Acharyya and Roy 2000; Roy et al. 2000; Acharyya 2001; Roy and Hanuma Prasad 2003; Naganjaneyulu and Santosh 2010 and references therein). A number of supracrustal belts including Mahakoshal, are recognized in the CITZ. The Mahakoshal supracrustal belt (MSB), which extends for about $600 \mathrm{~km}$, is characterized by metavolcanic rocks and metasediments (including carbonates, BIF, chert, phyllite, etc.) and younger intrusions of syenites, ultramafic rocks, variety of alkaline rocks, lamprophyres and granites. This reflects a greenstone association typical of a continental rift setting (Roy and Bandyopadhyay 1990; Jain et al. 1995a; Nair et al. 1995; Roy and Chakraborty 2008).

Most parts of the MSB are affected by regional greenschist to amphibolite facies metamorphism and belt is divided into three major stratigraphic formations: Chitrangi, Agori and Parsoi (Jain et al. 1995a). Most of the mafic-ultramafic and alkaline igneous rocks exposed in the study 
area are intruded within the Chitrangi Formation; Agori and Parsoi formations are almost devoid of any intrusive igneous rocks, but few lenses of metavolcanic rocks have been described from the Agori Formation. A number of metavolcanic flows have been reported all along the Mahakoshal supracrustal belt, but they are more profuse around Sleemanabad, Chitrangi and Jungel areas. Many of them are pyroclastic flows which indicate explosive nature of the volcanism. The available geochemical data on these metavolcanics suggest that they are derived from a melt generated by high degree melting of the shallow mantle source in a rift environment (Roy and Bandyopadhyay 1989; Thakur and Shukla 1990; Chaudhuri and Basu 1990; Kumar 1993; Raza et al. 2009).

Mafic-ultramafic, alkaline and carbonatitic intrusive rocks are well exposed within the MSB (Roy and Bandyopadhyay 1989; Jain et al. 1995a; Nair et al. 1995). Roy and Bandyopadhyay (1988) and Roy and Chakraborty (2008) classified the ultramafic rocks as lherzolitic peridotites, wehrlites and dunites, and later Srivastava and Chalapathi Rao (2007) reported alkaline lamprophyres from the Jungel area. The studied intrusive ultramafic rocks and associated carbonatites of this study are found from the Chitrangi region and are mainly exposed as dykes and plugs. It is difficult to identify carbonatite dyke in field due to high content of mafic silicate minerals (up to 30 vol.\%). Their appearance in field is similar to the other ultramafic dykes and they are properly identified as carbonatite dyke only after the petrography and geochemical studies. The majority of the intrusive rocks crosscut volcano-sedimentary sequences suggesting that they represent the youngest intrusive activity in this region. There is no radiometric age data available to confirm this inference. However, available geochronological data on rocks of the MSB indicate their ages between 2.5 and 1.6 Ga (Nair et al. 1995; Srivastava and Chalapathi Rao 2007). Nair et al. (1995) reported mineral isochron ages of an intrusive syenite and associated alkali gabbro which yielded 1.8 and $1.76 \mathrm{Ga}$, respectively. They also reported lamprophyre as a youngest magmatic event at $1610 \mathrm{Ma}$ in the MSB. There is no age data available for carbonatites. Although further robust geochronological ages are required to reach on any final conclusion, available data indicate that intrusive rocks, which also include ultramafic lamprophyre and carbonatite, are youngest magmatic activity in the MSB. This indicates their emplacement during the Paleoproterozoic $(\sim 1.6 \mathrm{Ga})$.

Ultramafic intrusive rocks of the study area are found either as ENE-WSW trending dykes (2$6 \mathrm{~m}$ in width and maximum $40-50 \mathrm{~m}$ in length; figure 2a) or small plugs (figure 2b) and are exposed all around the Chitrangi village and east of Chitrangi. These ultramafic rocks are mediumto coarse-grained and dark green in colour. A sharp contact between ultramafic rocks and supracrustal rocks (mostly phyllites of Agori Formation) can be observed in many places (figure 2c). At places they are deformed and altered. Roy and Chakraborty (2008) noticed schistosity in ultramafic rocks, defined by parallel alignment of serpentine fibers, which show small scale folds; this indicates that

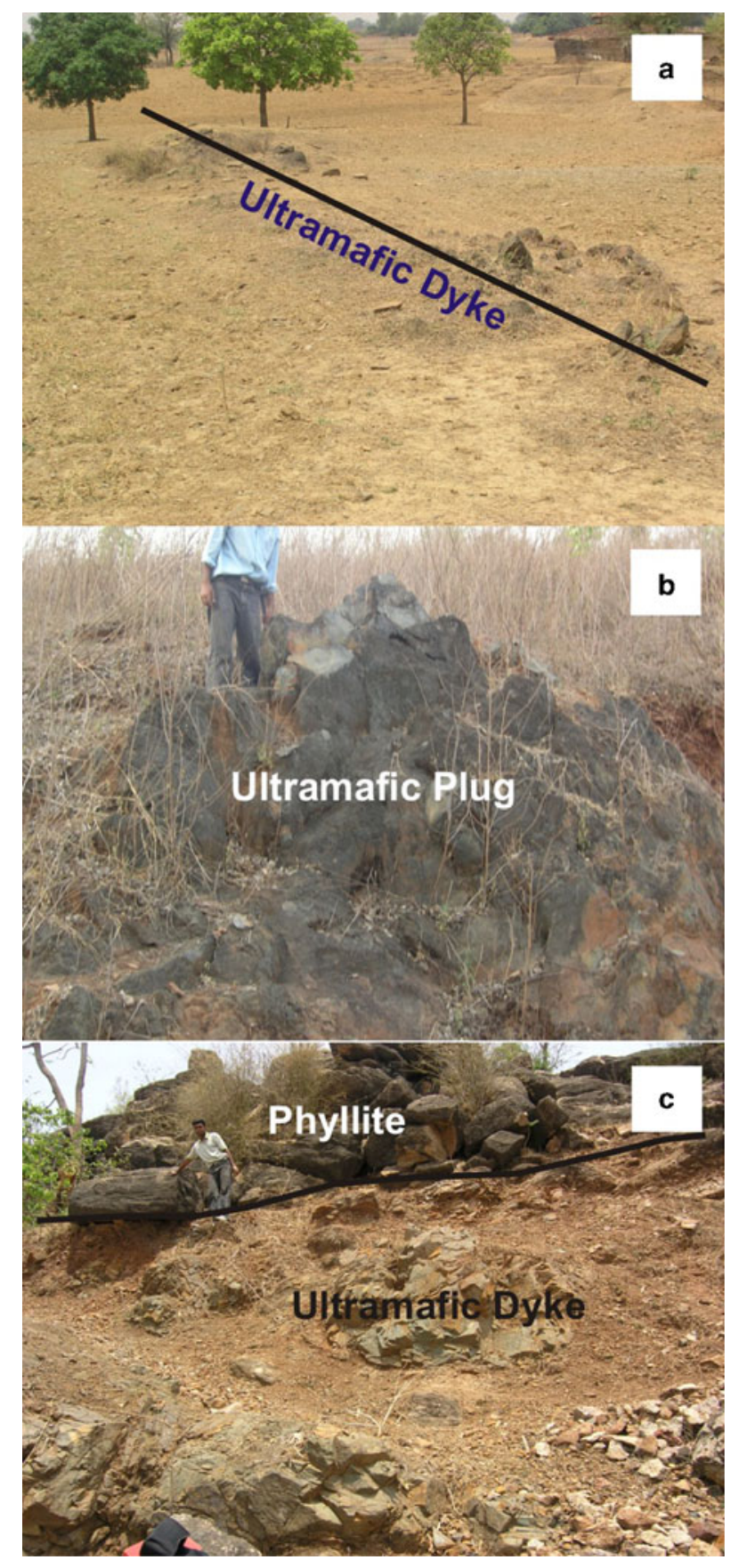

Figure 2. (a) An ENE-WSW trending ultramafic dyke exposed east of Chitrangi; (b) an ultramafic plug exposed near Chitrangi; and (c) a sharp contact between an ultramafic dyke and phyllite of Agori Formation. 


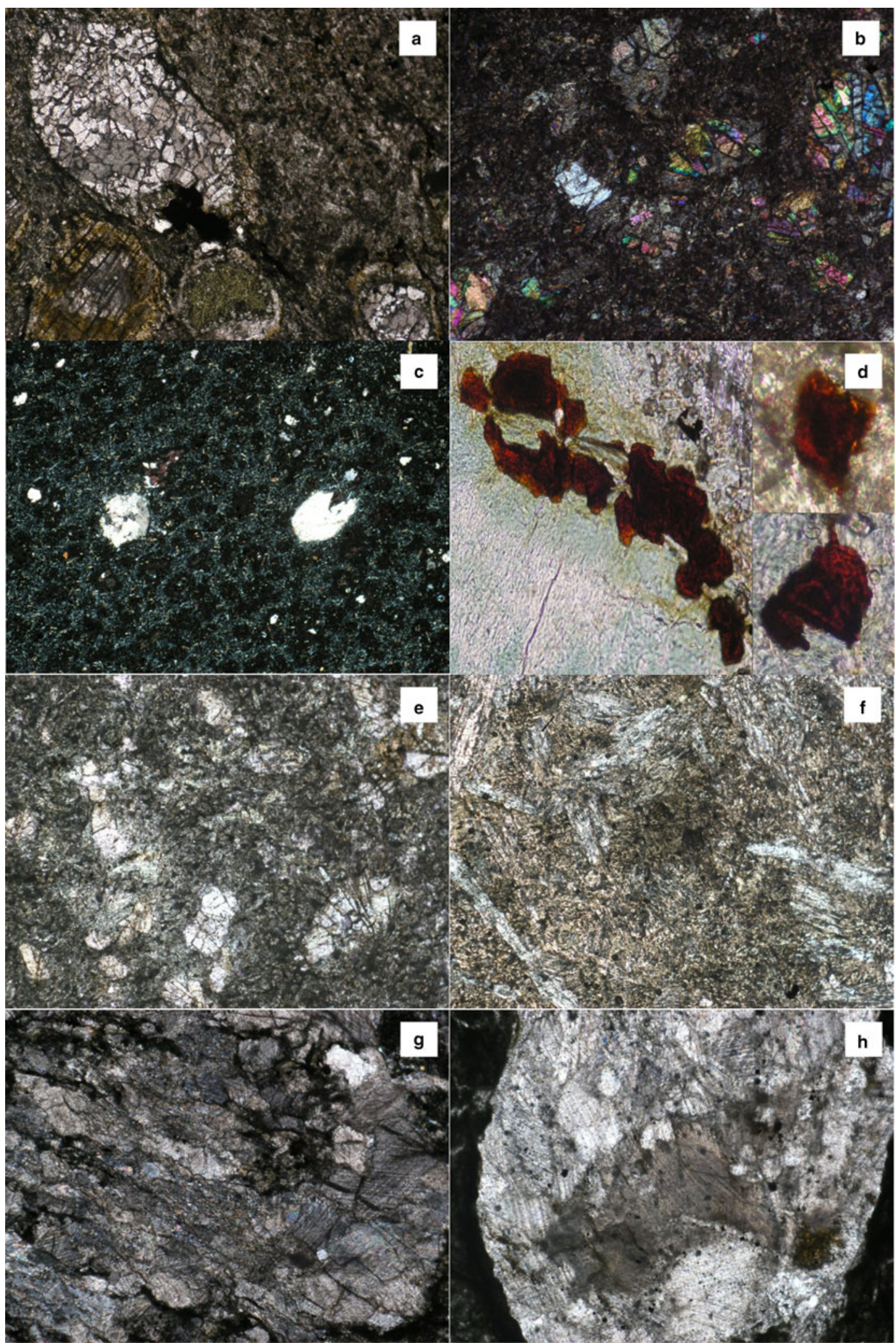

Figure 3. Photomicrographs show (a and b) porphyritic texture with several olivine phenocrysts, pseudomorphed by serpentine, carbonate and chlorite. (c) Carbonate ocelli and volatile rich minerals in an ultramafic sample. (d) Deep-brown coloured melanite granet grains encountered from ultramafic lamprophyres. Photographs are taken from three different samples. (e) Porphyritic texture with several olivine and phlogopite phenocrysts completely replaced by calcite and amphiboles. (f) Grano-nematoblastic texture due to complete greenschist facies metamorphism of an ultramafic rock. (g and $\mathbf{h}$ ) Most carbonatite samples show coarse-grained sövitic characteristics (figure $4 \mathrm{~g}, \mathrm{~h}$ ). Carbonatites with hypidiomorphic to interlocking texture dominated by calcite crystals. Except figure (d), width of photographs are $4 \mathrm{~mm}$; width of (d) is $1.5 \mathrm{~mm}$. 
ultramafic rocks were emplaced prior to the regional deformation in the MSB. Few small carbonatite dykes are also encountered around Chitrangi village. These carbonatite dykes contain appreciable amount of silicate minerals ( 20-30 vol.\%), particularly pyroxene, olivine and amphiboles. A simplified geological map of the Chitrangi area is presented in figure 1(c).

\section{Petrography}

Under the microscope, all the studied samples show evidence of low-grade (greenschist facies to low amphibolites facies $\mathrm{P}-\mathrm{T}$ conditions) metamorphism and hydrothermal alteration. Due to these post-magmatic processes it is difficult to find entirely fresh grains of igneous minerals. Pseudomorphs of phenocrystic olivines and phlogopite are recorded in most of the studied thin sections. Relicts of these minerals are still preserved and show characteristic optical properties. Same applies also for the groundmass. However, almost all the studied ultramafic rocks retain their original igneous textures; most show porphyritic texture and many samples also show glomeroporphyritic texture. The main phenocrysts reported in these rocks are olivine, phlogopite, and minor pyroxene which constitute about 25-35 vol.\% (see figure 3). Felsic phenocryst phases have not been observed. It is significantly important to observe melanite garnet (deep-brown in colour, high relief, zoned and isotropic; figure 3d) in a number of thin sections. Due to alteration of primary minerals, most of the thin sections also contain secondary serpentine, chlorite and carbonate minerals. Apatite, epidote, titanite, magnetite and ilmenite are common accessories.

Another noteworthy feature observed in a number of thin sections is the presence of rounded or elliptical carbonate ocelli (figure 3c). It is not straightforward to identify primary and secondary carbonate in the same sample by petrographic

Figure 4. (a) $\mathrm{TiO}_{2}$ vs. $\mathrm{Al}_{2} \mathrm{O}_{3}$ and (b) $\mathrm{MgO}$ vs. $\mathrm{SiO}_{2}$ discrimination plots for various alkaline mafic potassicultrapotassic rocks and Chitrangi ultramafic lamprophyres (fields adapted from Lefebvre et al. 2005). For comparison, field of Jharia potassic intrusive rocks with affinities to aillikites (Srivastava et al. 2009), Abloviak aillikite dykes (Digonnet et al. 2000), SW Greenland aillikite dykes (Nielsen et al. 2009) and Aillik Bay aillikite dykes (Tappe et al. 2006) are also shown. (c) Discrimination diagram for kimberlites and ultramafic lamprophyres (after Rock 1991). This also shows (grey shaded field) experimentally determined melt compositions after Gudfinnsson and Presnall (2005). The area between the $\mathrm{CO}_{2}$-free and carbonate-bearing solidi is taken from Dalton and Presnall (1998). Field of Aillik Bay aillikites is also shown for comparison (after Tappe et al. 2006). observations alone. Although it is possible that some calcite is secondary, the presence of carbonaterich ocelli is a good candidate to support presence of magmatic carbonate. Similar ocelli texture is also observed by Srivastava and Chalapathi Rao (2007) from the adjacent Jungel area. It would be appropriate to mention here that these
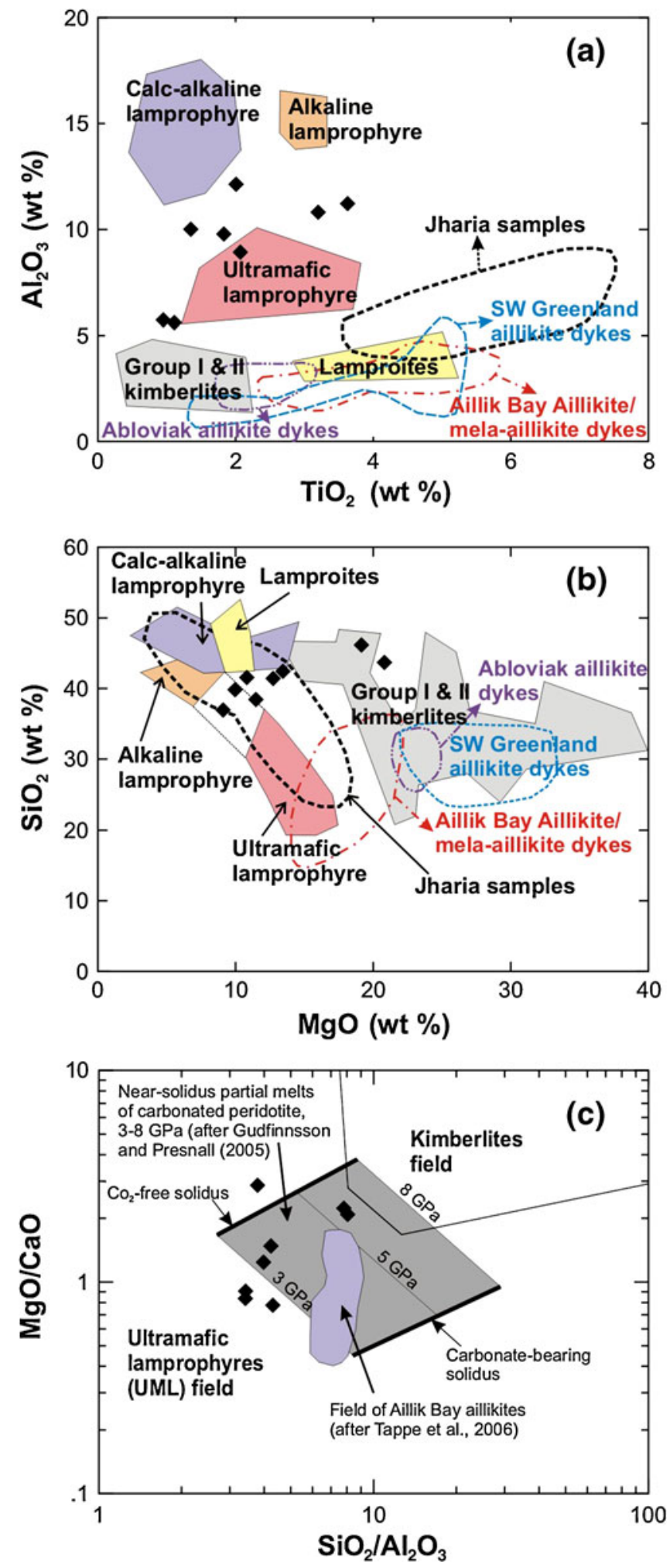
Table 1. Summary of field and petrographic features observed in the studied rocks from the Chitrangi region, Mahakoshal supracrustal belt, central India.

\begin{tabular}{|c|c|c|c|}
\hline Rock types & $\begin{array}{c}\text { Mode of } \\
\text { occurrence }\end{array}$ & Texture & $\begin{array}{l}\text { Essential mineral } \\
\text { composition }\end{array}$ \\
\hline $\begin{array}{l}\text { Ultramafic lamprophyre } \\
\text { (aillikite) }\end{array}$ & Dykes and plugs & $\begin{array}{l}\text { Medium- to coarse-grained; } \\
\text { porphyritic, glomeroporphyritic } \\
\text { and rarely grano-nematoblastic. } \\
\text { Ocellitic (ocelli filled } \\
\text { with calcite) }\end{array}$ & $\begin{array}{l}\text { Pseudomorphs (replaced } \\
\text { by calcite, amphibole and } \\
\text { chlorite) of olivines, } \\
\text { phlogopite and pyroxenes. } \\
\text { Carbonate (calcite), } \\
\text { melanite garnet, } \\
\text { serpentine, chlorite } \\
\text { and opaques }\end{array}$ \\
\hline $\begin{array}{l}\text { Carbonatite (sövite and } \\
\text { silico-carbonatite) }\end{array}$ & $\begin{array}{l}\text { Small dykes } \\
\text { and dykelets }\end{array}$ & $\begin{array}{l}\text { Coarse-grained; sövitic } \\
\text { (hypidiomorphic) }\end{array}$ & $\begin{array}{l}\text { More than } 60 \% \text { calcite and } \\
\text { pseudomorphs (replaced } \\
\text { by calcite, amphibole and } \\
\text { chlorite) of clinopyroxene, } \\
\text { phlogopite and olivine. } \\
\text { Apatite and opaques }\end{array}$ \\
\hline
\end{tabular}

Table 2. Estimated modal compositions of the studied rocks from the Chitrangi region, Mahakoshal supracrustal belt, central India.

\begin{tabular}{lccccccc}
\hline & Pyroxene & Olivine & Phlogopite & Carbonates & Chl/Amph & Feldspars & Accessories \\
\hline CH18 & $\mathrm{xxxx}$ & $\mathrm{xx}$ & $\mathrm{xx}$ & $\mathrm{xx}$ & $\mathrm{xx}$ & - & $\mathrm{x}$ \\
$\mathrm{CH} 22$ & $\mathrm{xxxx}$ & $\mathrm{x}$ & $\mathrm{xx}$ & $\mathrm{xx}$ & $\mathrm{xx}$ & $\mathrm{xx}$ & $\mathrm{x}$ \\
$\mathrm{CH} 23$ & $\mathrm{xxxx}$ & $\mathrm{xx}$ & $\mathrm{xx}$ & $\mathrm{xx}$ & $\mathrm{xx}$ & $\mathrm{x}$ & $\mathrm{x}$ \\
$\mathrm{CH} 26$ & $\mathrm{xxx}$ & $\mathrm{xx}$ & $\mathrm{xx}$ & $\mathrm{xx}$ & $\mathrm{xx}$ & $\mathrm{xx}$ & $\mathrm{x}$ \\
$\mathrm{CH} 27$ & $\mathrm{xxx}$ & $\mathrm{xx}$ & $\mathrm{xx}$ & $\mathrm{xxx}$ & $\mathrm{xxx}$ & $\mathrm{xx}$ & $\mathrm{x}$ \\
$\mathrm{CH} 32$ & $\mathrm{xxx}$ & $\mathrm{xx}$ & $\mathrm{x}$ & $\mathrm{xxx}$ & $\mathrm{xxx}$ & $\mathrm{xx}$ & $\mathrm{xx}$ \\
$\mathrm{CH} 33$ & $\mathrm{xxxx}$ & $\mathrm{x}$ & $\mathrm{xx}$ & $\mathrm{xxx}$ & $\mathrm{xxx}$ & - & $\mathrm{xx}$ \\
$\mathrm{CH} 34$ & $\mathrm{xxx}$ & $\mathrm{x}$ & $\mathrm{xx}$ & $\mathrm{xxx}$ & $\mathrm{xx}$ & $\mathrm{xx}$ & $\mathrm{x}$ \\
$\mathrm{CH} 20$ & $\mathrm{x}$ & - & - & $\mathrm{xxxx}$ & $\mathrm{x}$ & $\mathrm{x}$ & $\mathrm{x}$ \\
$\mathrm{CH} 24$ & $\mathrm{xx}$ & $\mathrm{xx}$ & $\mathrm{x}$ & $\mathrm{xxxx}$ & $\mathrm{xx}$ & $\mathrm{xx}$ & $\mathrm{x}$ \\
$\mathrm{CH} 30$ & $\mathrm{xx}$ & $\mathrm{x}$ & - & $\mathrm{xxxx}$ & $\mathrm{x}$ & $\mathrm{xx}$ & $\mathrm{x}$ \\
\hline
\end{tabular}

The symbol ' $\mathrm{x}$ ' denotes abundances of minerals present. Chl: chlorite; Amph: amphiboles.

rounded/elliptical carbonate bodies are possibly ocellae and not carbonate filled vesicles. This is well supported by two key features:

- studied ultramafic igneous rocks show intrusive nature; vesicles are usually observed in volcanic igneous rocks and

- normally samples with carbonate filled vesicles show very sharp boundary in comparison to ocelli. These distinguishing petrographic characteristics classify these rocks as ultramafic lamprophyres, possibly aillikites.

Although it is difficult to find fresh olivine grains (figure $3 \mathrm{a}, \mathrm{e}$ ), its original shape is still preserved (figure $3 \mathrm{a}, \mathrm{d}, \mathrm{e}$ ). Sometimes these grains have been entirely pseudomorphed by serpentine, carbonate and chlorite. Amphiboles, mainly hornblende (figure 3d, e) and tremolite/actinolite (figure 3f) are present in a number of samples. They are pale green, yellowish green and dark green in colour and euhedral to subhedral in shape and are part of the altered groundmass. Clinopyroxene is rarely found as pheonocryts and in the groundmass. Serpentine is found as an alteration product of olivine. Secondary calcite and chlorite are found as pseudomorphous after phlogopite and olivine (figure 3a, d, e). This is also supported by extremely low $\mathrm{K}_{2} \mathrm{O}$ contents that are discussed later in the geochemistry section.

Most carbonatite samples are coarse-grained, i.e., sövitic (figure $4 \mathrm{~g}, \mathrm{~h}$ ). They show hypidiomorphic to interlocking textures dominated by calcite grains and laths. Calcite is the main mineral constituent ( $\geq 60$ vol.\%), but due to low-grade metamorphism, dolomite is also identified. At places clinopyroxene, phlogopite and olivine crystals have been pseudomorphed by calcite, amphibole and chlorite and are present in appreciable amount ( $\sim 20-25$ vol.\%). Apatite, magnetite and ilmenite 
are common accessories. Few samples of carbonatite contain appreciable amount of silicate minerals ( $\sim 30-35$ vol.\%) which suggests their nature as silicic carbonatite, very close to aillikites. In fact, a sufficient amount of carbonate ( 15-20 vol.\%) is from the pseudomorphs of silicate minerals. Tables 1 and 2 present the summary of observed petrographic features and estimated modal compositions of the studied rocks.

\section{Analytical techniques}

Owing to pronounced post-magmatic alteration through hydrothermal and metamorphic processes,

Table 3. Whole rock major oxides (wt\%), trace and rare-earth element compositions of ultramafic lamprophyres and carbonatites from the Chitrangi region, Mahakoshal supracrustal belt, central India.

\begin{tabular}{|c|c|c|c|c|c|c|c|c|c|c|c|}
\hline \multirow[b]{2}{*}{ Sample no. } & \multicolumn{8}{|c|}{ Ultramafic lamprophyres } & \multicolumn{3}{|c|}{ Carbonatites } \\
\hline & CH18 & $\mathrm{CH} 22$ & $\mathrm{CH} 23$ & $\mathrm{CH} 26$ & $\mathrm{CH} 27$ & CH32 & CH33 & CH34 & $\mathrm{CH} 20$ & $\mathrm{CH} 24$ & CH30 \\
\hline $\mathrm{SiO}_{2}$ & 42.44 & 46.15 & 43.69 & 41.54 & 38.42 & 36.93 & 41.41 & 39.82 & 23.03 & 32.87 & 35.60 \\
\hline $\mathrm{TiO}_{2}$ & 3.63 & 0.95 & 1.11 & 2.00 & 2.07 & 3.20 & 1.83 & 1.35 & 1.30 & 1.69 & 0.76 \\
\hline $\mathrm{Al}_{2} \mathrm{O}_{3}$ & 11.22 & 5.73 & 5.61 & 12.13 & 8.93 & 10.81 & 9.79 & 10.01 & 4.90 & 7.80 & 8.59 \\
\hline $\mathrm{Fe}_{2} \mathrm{O}_{3}$ & 16.92 & 13.84 & 13.59 & 15.55 & 13.86 & 16.88 & 14.58 & 13.18 & 8.51 & 12.30 & 12.68 \\
\hline $\mathrm{MnO}$ & 0.18 & 0.11 & 0.15 & 0.19 & 0.17 & 0.12 & 0.18 & 0.17 & 0.10 & 0.15 & 0.36 \\
\hline $\mathrm{MgO}$ & 13.46 & 19.16 & 20.82 & 10.82 & 11.49 & 9.10 & 12.74 & 9.97 & 2.89 & 6.78 & 7.70 \\
\hline $\mathrm{CaO}$ & 4.70 & 9.17 & 9.32 & 11.94 & 14.78 & 10.88 & 8.61 & 8.03 & 30.36 & 20.74 & 12.70 \\
\hline $\mathrm{Na}_{2} \mathrm{O}$ & 0.03 & 0.11 & 0.08 & 0.97 & 0.69 & 1.27 & - & 0.85 & 0.23 & 1.76 & 1.83 \\
\hline $\mathrm{K}_{2} \mathrm{O}$ & 0.01 & 0.04 & 0.05 & 0.31 & 0.48 & 0.03 & 0.01 & 1.00 & 0.16 & 0.14 & 1.15 \\
\hline $\mathrm{P}_{2} \mathrm{O}_{5}$ & 0.35 & 0.13 & 0.12 & 0.24 & 0.26 & 0.33 & 0.19 & 0.18 & 0.28 & 0.24 & 0.15 \\
\hline LOI & 7.99 & 5.23 & 5.92 & 5.22 & 8.87 & 10.97 & 11.65 & 15.60 & 26.72 & 14.81 & 19.41 \\
\hline Total & 100.92 & 100.62 & 100.46 & 100.91 & 100.02 & 100.52 & 100.98 & 100.16 & 98.48 & 99.28 & 100.93 \\
\hline $\operatorname{Mg}^{*}$ & 65.03 & 76.39 & 78.17 & 61.01 & 65.08 & 54.80 & 67.13 & 63.88 & 43.30 & 55.35 & 58.67 \\
\hline $\mathrm{Cr}$ & 300 & 1660 & 1700 & 1370 & 750 & 190 & 840 & 340 & 210 & 900 & 70 \\
\hline $\mathrm{Ni}$ & 100 & 1120 & 931 & 610 & 400 & - & - & - & 30 & 580 & 60 \\
\hline $\mathrm{Sc}$ & 36 & 21 & 24 & 32 & 29 & 49 & 35 & 29 & 8 & 24 & 16 \\
\hline $\mathrm{V}$ & 387 & 156 & 176 & 317 & 253 & 413 & 258 & 222 & 119 & 202 & 97 \\
\hline $\mathrm{Rb}$ & - & 2 & - & 9 & 7 & - & - & 29 & 4 & 3 & 10 \\
\hline $\mathrm{Ba}$ & 15 & 36 & 14 & 145 & 999 & 16 & 10 & 342 & 42 & 140 & 508 \\
\hline $\mathrm{Sr}$ & 48 & 26 & 55 & 643 & 389 & 136 & 31 & 199 & 245 & 476 & 174 \\
\hline $\mathrm{Nb}$ & 32 & 11 & 11 & 20 & 22 & 30 & 15 & 10 & 20 & 21 & 16 \\
\hline $\mathrm{Ta}$ & 2.2 & 0.8 & 0.7 & 1.5 & 1.5 & 1.9 & 0.9 & 0.6 & 1.3 & 1.3 & 1.2 \\
\hline $\mathrm{Zr}$ & 217 & 63 & 77 & 145 & 152 & 238 & 122 & 100 & 136 & 126 & 102 \\
\hline $\mathrm{Hf}$ & 6.5 & 1.9 & 2.4 & 3.8 & 4.3 & 4.3 & 2.3 & 1.9 & 3.4 & 3.4 & 1.7 \\
\hline $\mathrm{Y}$ & 25 & 10 & 11 & 18 & 18 & 27 & 20 & 17 & 8 & 15 & 19 \\
\hline $\mathrm{Ga}$ & 23 & 10 & 10 & 24 & 15 & 3 & 2 & 1 & 13 & 13 & - \\
\hline Th & 2.6 & 0.9 & 1.1 & 1.8 & 1.8 & 2.2 & 1.2 & 0.7 & 1.6 & 1.4 & 4.1 \\
\hline$\underline{\mathrm{U}}$ & 0.6 & 0.2 & 0.2 & 0.4 & 0.4 & 0.4 & 0.3 & 0.1 & 0.5 & 0.4 & 0.5 \\
\hline $\mathrm{La}$ & 27.00 & 7.30 & 11.00 & 20.00 & 21.60 & 44.70 & 20.50 & 21.00 & 16.70 & 21.60 & 42.10 \\
\hline $\mathrm{Ce}$ & 65.10 & 18.30 & 24.10 & 46.10 & 49.20 & 89.00 & 42.70 & 42.30 & 36.60 & 47.50 & 67.40 \\
\hline $\operatorname{Pr}$ & 8.83 & 2.67 & 3.23 & 5.99 & 6.38 & 9.90 & 4.94 & 4.85 & 4.66 & 6.00 & 7.13 \\
\hline $\mathrm{Nd}$ & 35.70 & 11.20 & 13.10 & 23.80 & 25.40 & 40.70 & 21.00 & 19.80 & 18.30 & 23.40 & 27.00 \\
\hline $\mathrm{Sm}$ & 7.80 & 2.60 & 2.90 & 5.10 & 5.40 & 9.20 & 5.10 & 4.40 & 3.80 & 4.70 & 5.20 \\
\hline $\mathrm{Eu}$ & 2.98 & 0.82 & 1.03 & 1.88 & 1.86 & 3.10 & 1.67 & 1.59 & 1.23 & 1.68 & 1.52 \\
\hline $\mathrm{Gd}$ & 7.50 & 2.60 & 2.90 & 5.20 & 5.30 & 7.10 & 4.30 & 3.70 & 3.20 & 4.40 & 3.90 \\
\hline $\mathrm{Tb}$ & 1.20 & 0.40 & 0.50 & 0.80 & 0.80 & 1.10 & 0.70 & 0.60 & 0.50 & 0.70 & 0.60 \\
\hline Dy & 6.20 & 2.50 & 2.60 & 4.30 & 4.60 & 6.10 & 4.00 & 3.50 & 2.20 & 3.70 & 3.60 \\
\hline Ho & 1.10 & 0.50 & 0.50 & 0.80 & 0.80 & 1.00 & 0.70 & 0.60 & 0.30 & 0.70 & 0.60 \\
\hline Er & 2.60 & 1.20 & 1.30 & 1.90 & 2.00 & 2.40 & 1.80 & 1.50 & 0.70 & 1.60 & 1.60 \\
\hline $\mathrm{Tm}$ & 0.32 & 0.15 & 0.17 & 0.23 & 0.25 & 0.30 & 0.23 & 0.20 & 0.08 & 0.20 & 0.20 \\
\hline $\mathrm{Yb}$ & 1.70 & 0.90 & 1.00 & 1.30 & 1.30 & 1.60 & 1.30 & 1.20 & 0.40 & 1.10 & 1.10 \\
\hline $\mathrm{Lu}$ & 0.22 & 0.11 & 0.13 & 0.17 & 0.18 & 0.22 & 0.19 & 0.17 & 0.06 & 0.15 & 0.15 \\
\hline
\end{tabular}

-: below detection limit; *: Mg\# calculated by SINCLAS computer program (Verma et al. 2002). 
very cautious sampling has been done during the field-trips to ensure that the selected samples were as fresh as possible. Before powdering they were re-checked for any veining or alteration. Eleven (eight from ultramafic rocks and three from carbonatites) samples, representing complete range of mineralogical variation observed in these rocks, were selected for whole-rock analyses of major oxides and trace elements. All analyses were done at the Activation Laboratories Ltd., Ancaster, Ontario, Canada. ICP-OES (Model: Thermo-JarretAsh ENVIRO II) was used to analyse the major elements, whereas ICP-MS (Model: Perkin Elmer Sciex ELAN 6000) was used to determine trace element concentrations. The precision is approximately $5 \%$ and $5-10 \%$ for the major oxides and trace elements, respectively, when reported at $100 \times$ detection limit. The analytical procedure is detailed by Gale et al. (1997) and the details are available in the Activation Laboratories Ltd. website (http://www.actlabs.com). Several standards, such as MRG1, W2, DNC1, STM1 and SY3, were run to check accuracy and precision. All the chemical data are presented in table 3 .

\section{Geochemistry}

Studied ultramafic rocks show $\mathrm{SiO}_{2}$ (36.9347.22 wt\%), high $\mathrm{MgO}$ (9.10-20.82 wt\%), high Ni (up to $1120 \mathrm{ppm}$ ), high Cr (up to $1700 \mathrm{ppm}$ ), moderate-to-high $\mathrm{CaO}$ (4.70-14.78 wt\%), high $\mathrm{TiO}_{2}$ (up to $3.63 \mathrm{wt} \%$ ), and high loss-on-ignition values (5.22-15.60 wt\%). Low $\mathrm{K}_{2} \mathrm{O}$ concentration (0.01-1.0 wt\%) observed in these rocks are probably due to alteration of mica (phlogopite) into chlorite and calcite. Carbonatitic members show extremely low $\mathrm{SiO}_{2}(23.03-35.60$ wt\%), high $\mathrm{CaO}$ (12.70-30.36 wt\%) but low $\mathrm{MgO}(2.89-7.70 \mathrm{wt} \%)$ and high loss-on-ignition values (14.81-26.72 wt\%). One sample of carbonatitic variety has high $\mathrm{Cr}$ and $\mathrm{Ni}$ contents (900 and $580 \mathrm{ppm}$ respectively; see table 3). These geochemical characteristics evidently indicate that the both rock types (ultramafic rock and carbonatites) include samples that crystallized from nearly pristine mantle-derived melts. High $\mathrm{Mg} \#$ (as high as 78) observed in many samples also corroborates their derivation from primary melts.

Petrographic properties of the studied ultramafic and carbonatitic rocks classify them as carbonaterich ultramafic lamprophyres (possibly aillikites) and calcite carbonatite $(\geq 60 \%$ carbonate minerals). The IUGS recommendations for classifying igneous rocks do not include ultramafic lamprophyres (Le Maitre 2002), but there are many distinguishing features that separate ultramafic lamprophyres from kimberlites, orangeites and lamproites, and it needs appropriate place in the IUGC classification schemes. Tappe et al. (2005) discussed this issue in detail and suggested some modification in the existing IUGS classification
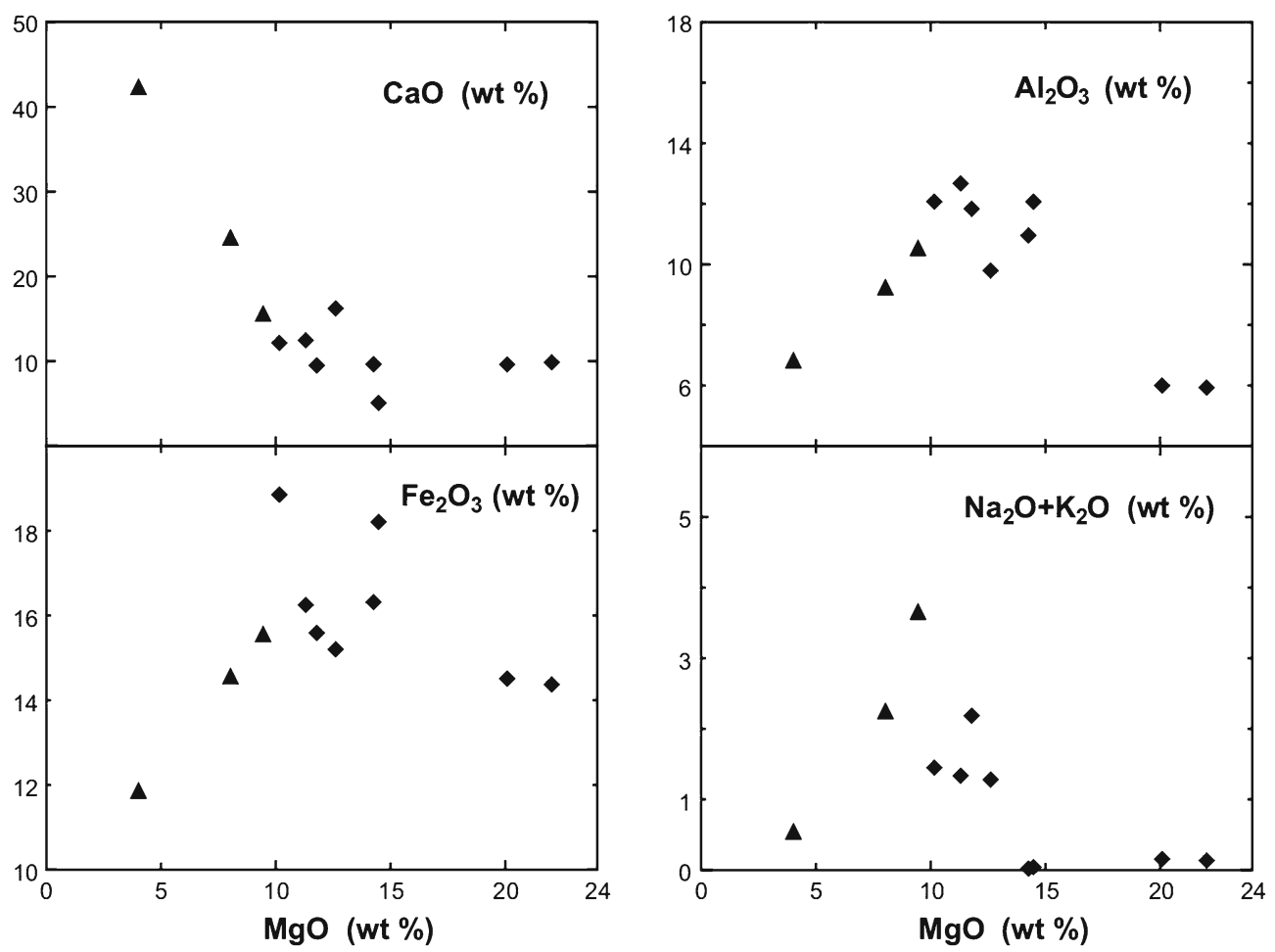

Figure 5. Variations of few major oxides against MgO. $\bullet$ : ultramafic lamprophyres and $\boldsymbol{\Delta}$ : carbonatites. 
scheme with inclusion of ultramafic lamprophyres. They pointed out that ultramafic lamprophyres can be readily distinguished from olivine lamproites by the occurrence of primary carbonates, and from orangeites and kimberlites by the presence of groundmass clinopyroxene and Ti-rich primary garnet.

Few geochemical discrimination diagrams have been used to discriminate ultramafic lamprophyres from the other alkaline mafic/ultramafic rocks, viz., kimberlite I (archetypal kimberlite), kimberlite II (orangeites), lamproites, alkali lamprophyres and calc-alkaline lamprophyres (figure 4). On these plots all the studied lamprophyres indicate their ultramafic lamprophyre nature (figure $4 \mathrm{a}$ and b; Lefebvre et al. 2005). Chitrangi lamprophyres are readily different from the other similar rocks such as lamproites, calc-alkaline lamprophyres and Group I \& II kimberlites; most samples plot close the fields of ultramafic and alkaline lamprophyres. It is worth to mention that there is no petrogenetic difference between ultramafic and alkaline lamprophyres; actually they have similar petrogenetic history (Tappe et al. 2005). If this is true, most of the studied samples clearly show their ultramafic lamprophyre nature. Another discrimination diagram suggested by Rock (1991) also discriminate studied ultramafic lamprophyres from kimberlites (figure 4c). Therefore, these discrimination diagrams clearly classify studied rocks as ultramafic lamprophyres; no kimberlitic nature is observed.

Geochemical characteristics of the studied rocks are examined on many variation plots, however in many cases they do not show any significant trend. This is understandable as these rocks have undergone post-magmatic processes which are evident from their mineral composition. It is known that the large ion lithophile elements (LILE; such as $\mathrm{Sr}, \mathrm{K}, \mathrm{Rb}, \mathrm{Ba}$, etc.,) are generally mobile during post-magmatic processes (Seewald and Seyfried 1990; Verma 1992; Rollinson 1993; Condie and

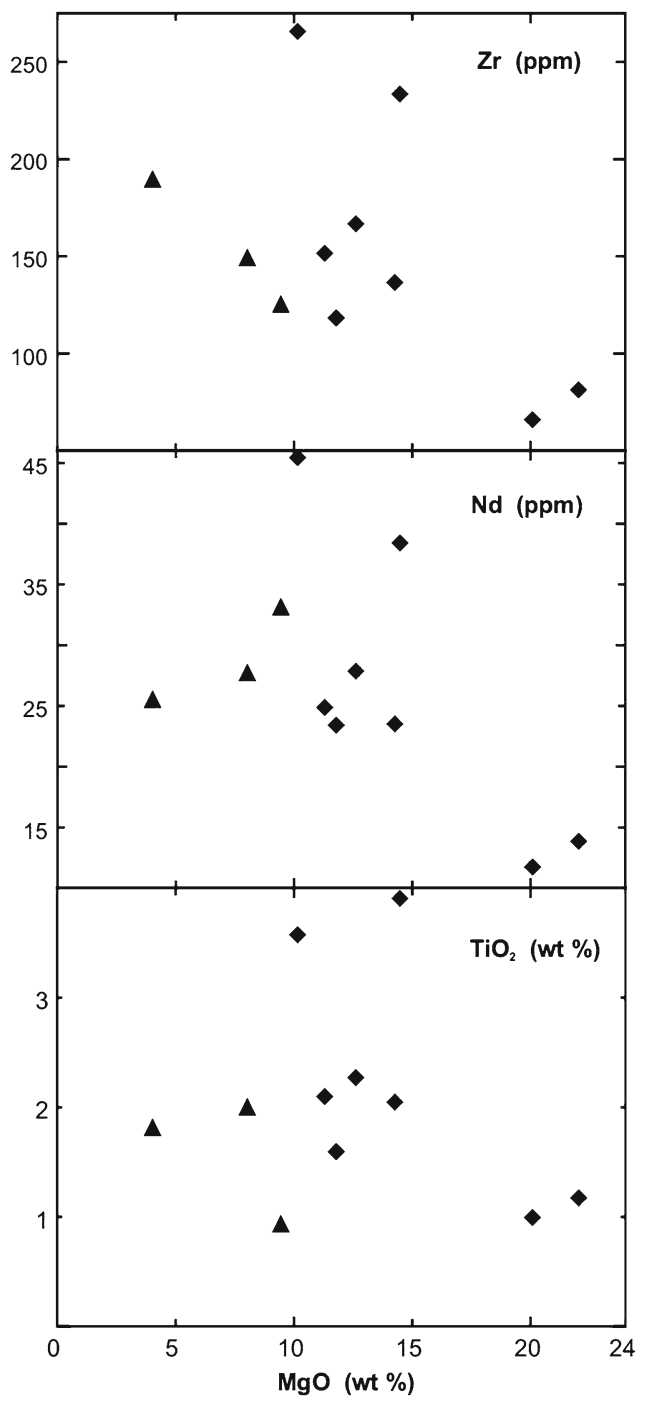

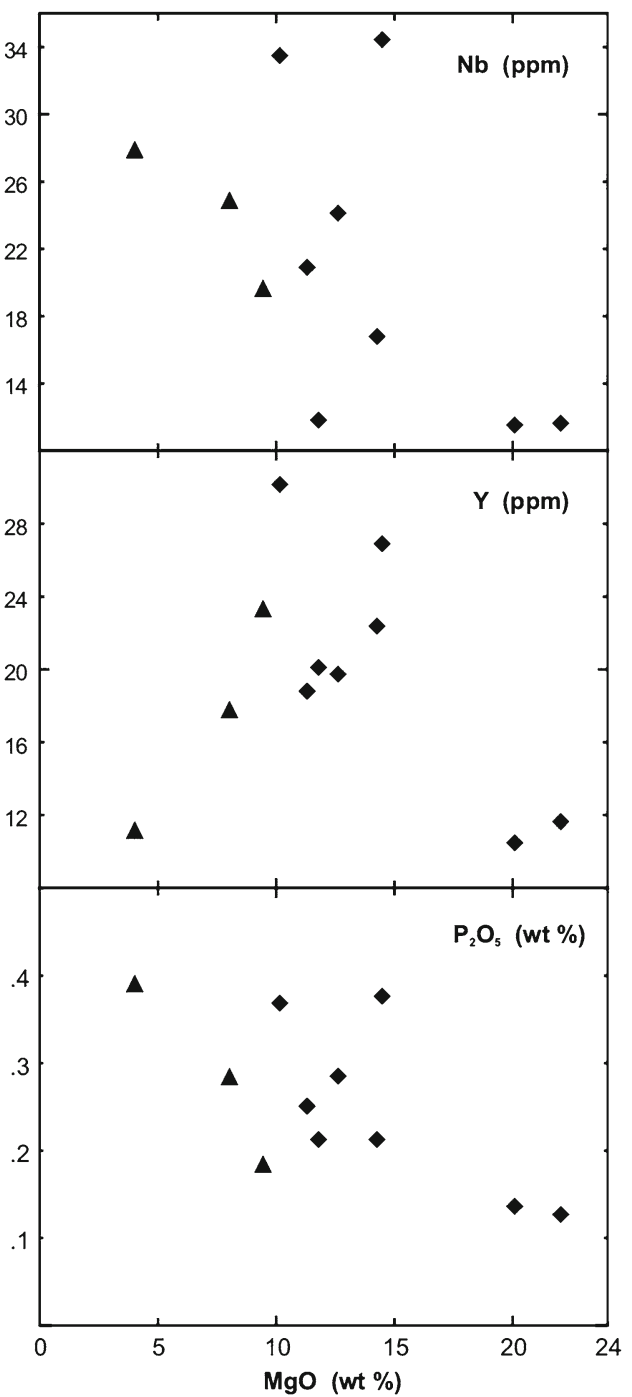

Figure 6. Variations of HFSEs against MgO. Symbols are same as in figure 5. 
Sinha 1996). Probably due to this reason many LILE do not show any significant crystallization trend. However, few major element variation diagrams show some important features (figure 5). Ultramafic lamprophyre samples show reasonably good crystallization trends. $\mathrm{MgO}-\mathrm{CaO}$ and $\mathrm{MgO}$-alkalis increase with decreasing $\mathrm{MgO}$ contents in the carbonatite samples and following ultramafic lamprophyre trends, however $\mathrm{Al}_{2} \mathrm{O}_{3}$ and $\mathrm{Fe}_{2} \mathrm{O}_{3}$ show positive correlation with $\mathrm{MgO}$ and do not follow ultramafic lamprophyre trends. On the basis of these observations it is difficult to establish any co-genetic relationship between ultramafic lamprophyre and carbonatite samples.

On another variation diagram, some high-field strength elements (HFSEs) are plotted against
$\mathrm{MgO}$ contents (figure 6). HFSEs, such as $\mathrm{Y}, \mathrm{Zr}$, $\mathrm{P}, \mathrm{Nb}, \mathrm{Ti}, \mathrm{Hf}, \mathrm{Ce}$ and $\mathrm{Nd}$, are supposed to be immobile during the low-grade metamorphism and hydrothermal alterations (Pearce and Cann 1973; Winchester and Floyd 1976; Floyd and Winchester 1978; Rollinson 1993; Jochum and Verma 1996). Largely, in all plots HFSEs of ultramafic lamprophyre samples show negative correlation with $\mathrm{MgO}$ suggesting normal differentiation behaviour and crystallization of minor minerals like zircon, titanite, and apatite at later stages. Again it is difficult to establish any specific genetic co-relation between ultramafic lamprophyre and carbonatite samples. In most plots carbonatite samples show different crystallization behaviour than the ultramafic lamprophyre samples thus indicating different genetic
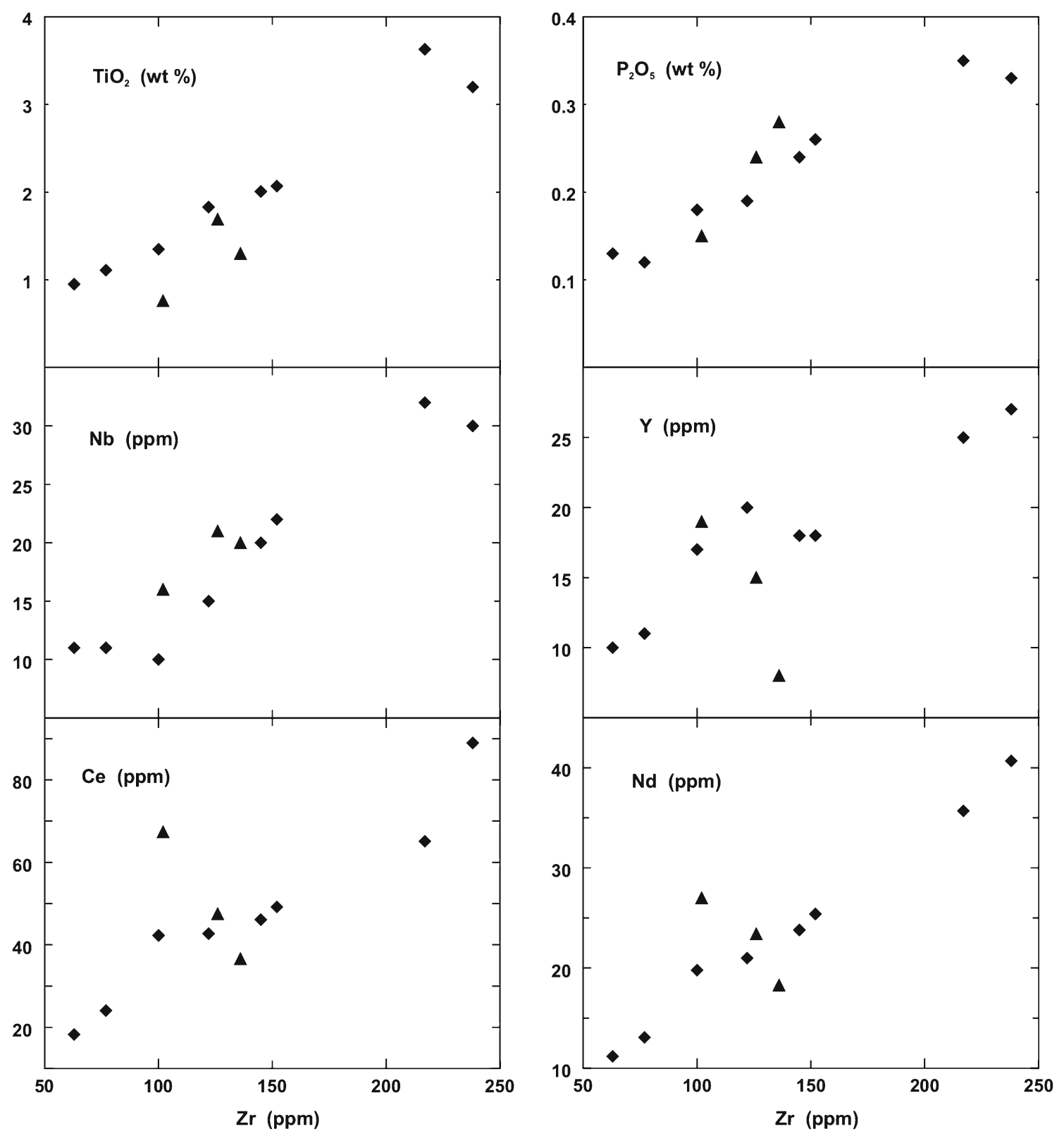

Figure 7. Variations of HFSEs against Zr. Symbols are same as in figure 5. 
histories for them. In many cases $\mathrm{Zr}$ is used as an index of differentiation, therefore, few HFSEs are plotted against Zr to re-check the above observations (figure 7). In all the plots ultramafic lamprophyre samples show good differentiation trends, whereas in few plots carbonatite samples do not follow ultramafic lamprophyre trends. This obviously support that ultramafic lamprophyre samples show their co-genetic nature, however it is difficult to establish any straightforward genetic relationship between ultramafic lamprophyre and carbonatite.

Primitive mantle-normalized multi-element spidergrams and chondrite-normalized rare-earth element (REE) patterns are displayed in figure 8 . Both ultramafic lamprophyres and carbonatite samples show enriched concentrations of plotted elements in comparison to primordial mantle and chondrite. Significant features noted on the multielement spidergrams include:

- LILEs (Rb, Ba, K and Sr) show wide variation in both types; this probably reflects post-magmatic alteration. In contrast, HFSEs show consistent patterns suggesting their genetic association with each other.

- One carbonatite sample (CH24) shows negative $\mathrm{Sr}$, Hf and Ti anomalies, whereas $\mathrm{K}$ shows positive anomaly which are not observed in other two carbonatite samples. This suggests some different genetic history for $\mathrm{CH} 24$.

- There are no significant negative $\mathrm{Nb}$ or $\mathrm{Ta}$ anomalies noticeable in either type; in contrast few samples have slightly positive $\mathrm{Nb}$ and $\mathrm{Ta}$ anomalies. This feature clearly supports continental mantle origin for these rocks.

Significant features observed in REE patterns are:

- Inclined REE patterns (LREE $>$ HREE) are noted from both the types. $\mathrm{La}^{\mathrm{N}} / \mathrm{Lu}^{\mathrm{N}}$ is comparatively higher in carbonatites than in ultramafic lamprophyres (between 8 and 20 for ultramafic lamprophyres and three carbonatite samples have this ratio 15, 29 and 34).

- The observed depletion in HREE suggests their derivation by partial melting of garnet bearing mantle.

- All ultramafic lamprophyre samples show almost similar REE patterns. Variation in LREE simply reflects melt fractionation trends.

- All the three carbonatite samples show different REE patterns; in comparison to $\mathrm{CH} 30, \mathrm{CH} 20$ shows more depletion in HREE and $\mathrm{CH} 24$ shows more LREE enrichment. As stated above, CH24 have entirely different multi-element spidergram. Most likely these were crystallized from different carbonate melts; it is difficult to explain genesis
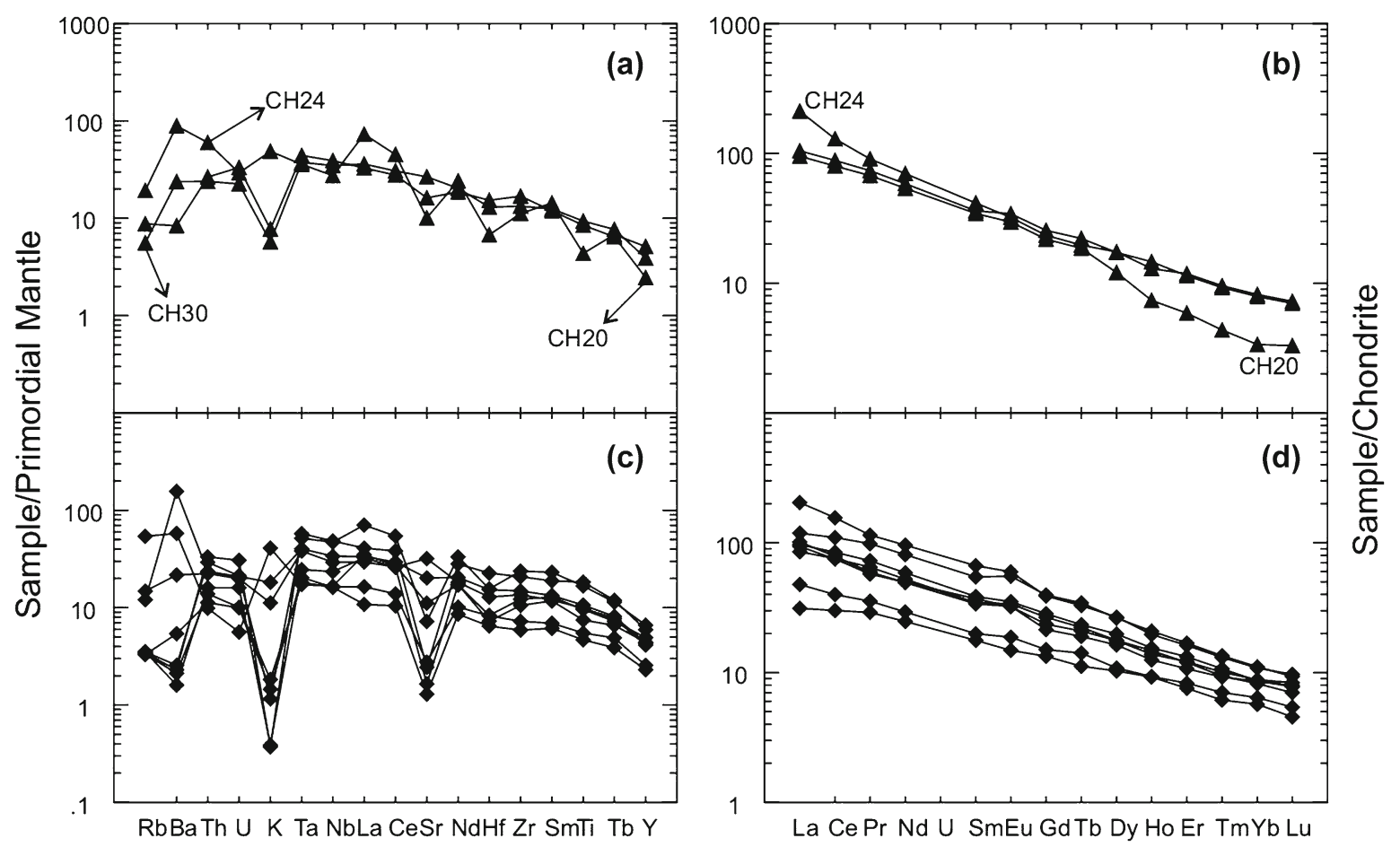

Figure 8. Primordial mantle normalized multi-element spidergrams and chondrite normalized rare-earth element patterns for the Chitrangi ultramafic lamprophyres and carbonatites. Primordial mantle and chondrite values are taken from McDonough et al. (1992) and Evensen et al. (1978). 
of these samples by a simple differentiation from a common melt. It is most likely that melts from different depths or some different mechanism were responsible for crystallization of carbonatites.

\section{Discussion}

It is difficult to establish any simple petrogenetic process for the studied rocks from their observed geochemical characteristics. This is because they do not show any straightforward genetic relationship with each other. Their geochemical characteristics indicate genesis through different processes and different melts. Before going to discuss petrogenetic processes in detail, it is essential to comment any possibility of crustal contamination and the tectonic environment of their emplacement.

Although the studied rocks, both aillikites and carbonatites, show wide range of major oxides and large ion lithophile elements (LILE), their high-field strength element (HFSE) concentrations are very consistent. The wide range of major oxides and LIL elements are probably due to postmagmatic processes. There are many geochemical characteristics shown by the studied rocks that do not support significant crustal contamination of the parental magmas. These include:

- there is no negative anomaly observed either for $\mathrm{Nb}$ or $\mathrm{Ta}$ on multi-element spidergrams (figure 8). Crustally contaminated samples usually show strong negative anomalies in Nb-Ta.

- All samples show inclined REE patterns, no LREE enrichment with flat HREE pattern is noticed in any samples; crustally contaminated samples show LREE enrichment with flat HREE pattern.

- High Mg\# with high $\mathrm{Ni}$ and $\mathrm{Cr}$ contents (see table 3) in many samples also preclude possibility of crustal contamination as these geochemical features are considered to indicate a 'primitive' nature of the magma. High $\mathrm{Mg} \#$ with low silica contents also supports above observations. $\mathrm{Zr} / \mathrm{Y}$ and $\mathrm{Nb} / \mathrm{Y}$ ratios of these rocks further corroborate their primitive nature; most samples indicate deep-mantle source and plume signature (see figure 9; Fitton et al. 1997; Baksi 2000). Therefore, on the basis of these diagnostic geochemical characteristics it may be concluded that studied ultramafic lamprophyre and carbonatite samples do not show significant sign of crustal contamination. As a result HFSE concentrations of studied samplers may be used for suggesting their tectonic environment of emplacement and petrogenesis.

Occurrences of ultramafic lamprophyres have been suggested to be associated with a lithospheric

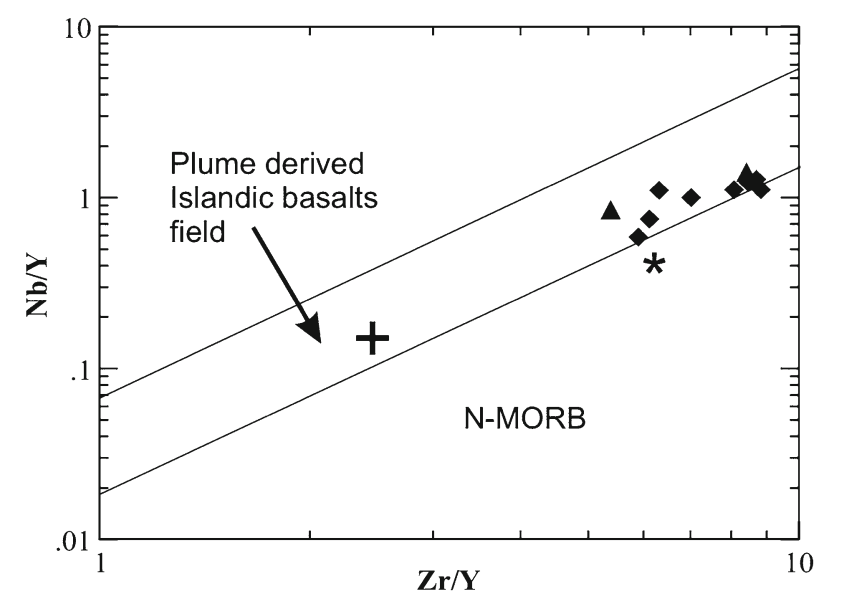

Figure $9 . \mathrm{Nb} / \mathrm{Y}$ vs. $\mathrm{Zr} / \mathrm{Y}$ ratio plot for Icelandic basalts with $\mathrm{MgO}>5 \%$, and N-MORB, primordial mantle ( + : after McDonough and Sun 1995), and average continental crust (*: after Rudnick and Fountain 1995), compared with studied ultramafic lamprophyres and carbonatites. Symbols are same as in figure 5.

extension (Rock 1986; Tappe et al. 2006), however, it is essential to verify this tectonic environment for the present studied rocks with available geological features and geochemistry. Field setting and lithological features of the Mahakoshal Supracrustal Belt clearly reflect its greenstone association typically developed in a continental rift setting (Roy and Bandyopadhyay 1990; Nair et al. 1995; Jain et al. 1995b; Roy and Hanuma Prasad 2003). Recently, Srivastava (2012) discussed all the available tectonic models for this region and suggested that the Chitrangi region experienced N-MORB type mafic magmatism around $2.5 \mathrm{Ga}$ and withinplate mafic, ultramafic and alkaline magmatism around $1.5-1.8 \mathrm{Ga}$.

Geochemical compositions, such as the absence of any significant negative $\mathrm{Nb}$ or Ta anomaly on multi-element spidergrams (see figure 8) of the studied rocks also support their emplacement in an extensional tectonic environment. Some tectonic discrimination diagrams, wholly based on HFSEs, are also tested to confirm this feature (figure 10). In them all the studied samples exclusively suggest their emplacement in a within-plate tectonic environment (figure 10; Pearce and Cann 1973; Pearce and Norry 1979; Wood 1980; Meschede 1986).

On the basis of geochemical characteristics of the studied rocks, presented in above sections, following conclusions may be drawn:

- The studied samples, ultramafic lamprophyre (close to aillikitic nature) or carbonatite, did not crystallize from a single melt. Possibly different melts were responsible for their genesis. This is well supported by their geochemical characteristics. 

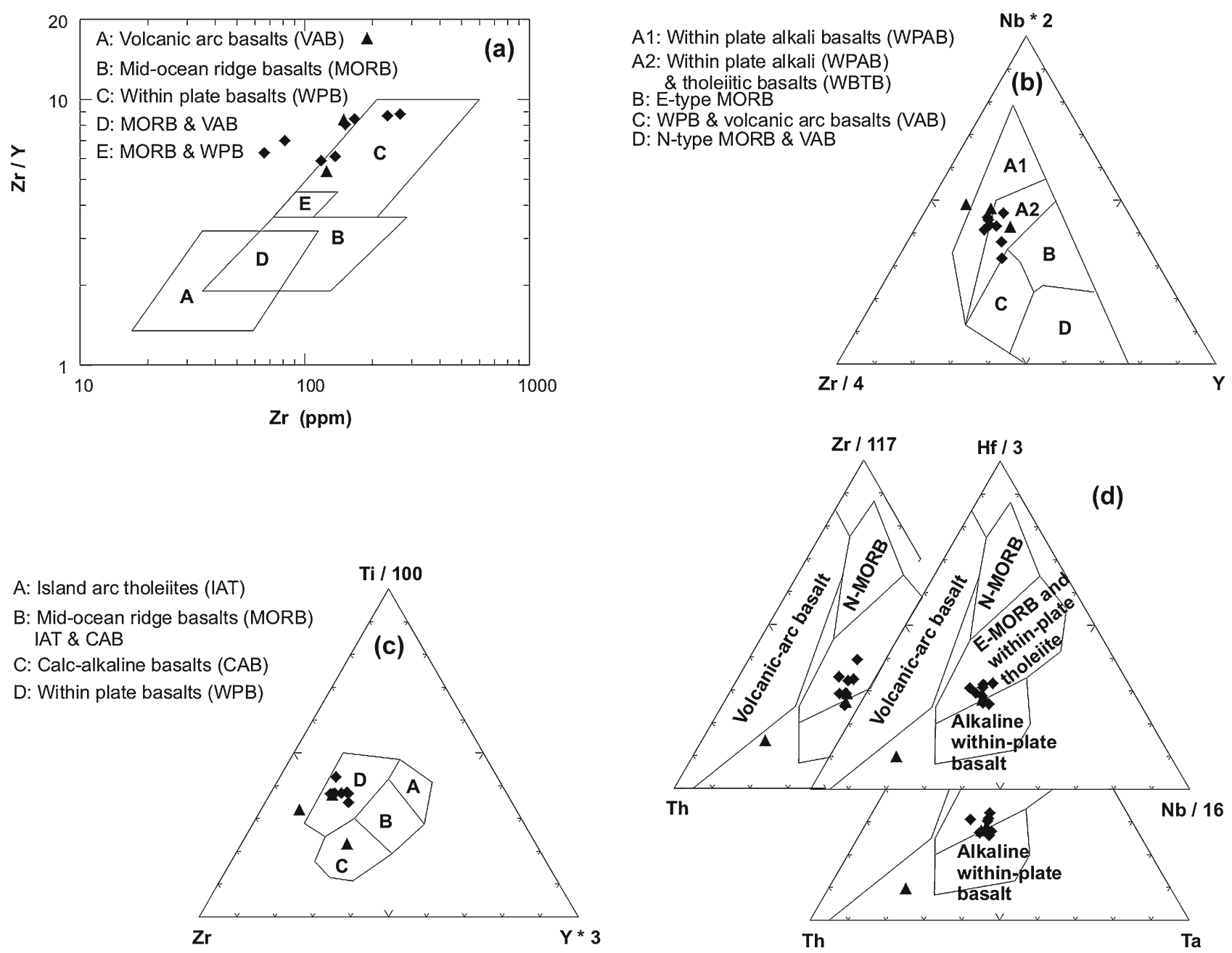

Figure 10. Discrimination diagrams for distinguishing tectonic environments. (a) Zr/Y-Zr discrimination diagram (after Pearce and Norry 1979); (b) Zr-Nb-Y discrimination diagram (after Meschede 1986) (c) Ti-Zr-Y discrimination diagram (after Pearce and Cann 1973); and (d) discrimination diagrams based on Zr-Th-Nb, Hf-Th-Nb and Hf-Th-Ta (Wood 1980).

- From the chemistry it is difficult to establish any direct genetic relationship between carbonatite and ultramafic lamprophyre samples.

- Ultramafic lamprophyre with high Mg\# (up to $\sim 78$ ), and high $\mathrm{Ni}$ and $\mathrm{Cr}$ contents (up to $~ 1700$ and $\sim 1100$, respectively) obviously suggest their derivation from a near-primary mantle-derived magmas (Frey et al. 1978).

- Inclined REE pattern (LREE>HREE) with low HREE concentration in the studied samples suggest melting in the presence of residual garnet.

- Presence of carbonate ocelli obviously indicate late stage liquid immiscibility mechanism; a mantle derived melt splits into silicate and carbonate melts which ultimately crystallized into ultramafic lamprophyres and carbonatites (Ferguson and Currie 1971; Hamilton et al. 1979; Mitchell 2005). Genesis of ultramafic lamprophyres and carbonatites through liquid immiscibility process is very common and reported from many areas (e.g., Rock 1987, 1991; Foley 1984; Mitchell 2005; Vichi et al. 2005; Tappe et al. 2006 and references therein).

Since the study area comprises both carbonatites and silicate rocks, it is possible that the distinct parental magmas might have been derived by liquid immiscibility; however, the geochemical characteristics shown by these rocks create some uncertainty. Before discussing this problem locally, it is worth to discuss genesis of carbonatites and associated silicate rocks in general. In terms of mineralogical-genetic classifications, Mitchell (2005) classified carbonatites into three types, i.e., carbonatites

- derived from an asthenospheric mantle-derived melts. Such carbonatites are usually associated with a wide range of alkaline silicate rocks (melilitite, nephelinite, aillikite and kimberlite), 
- derived from predominantly metasomatized lithospheric mantle. These are normally associated with potassic and sodic peralkaline magmas, and

- formed by pneumatolytic melting of crustal rocks (not a true carbonatite), and hence coined pseudocarbonatites.

In this study, an aillikite-carbonatite association is observed and many geochemical characteristics suggest their mantle origin. Therefore, it may be classified as first type described by Mitchell (2005). There are three possibilities which can explain genesis of carbonatite and associated silicate rocks. These are:

- fractional crystallization of primary carbonatite nephelinite melt or

- an immiscible liquid that separates from a fractionated silicate magma of nephelinitic/ phonolitic composition or

- distinct melt that directly originated by lowdegree melting of a carbonated mantle peridotite. It is important to mention that a co-genetic relationship can be established between carbonatite and silicate rocks through first two models; however it is difficult to establish this relationship by third model (Gittins 1989; Bailey 1993; Gittins and Harmer 2003).

Considering geochemical features observed for the studied rocks, it is difficult to reach on any straightforward conclusion for their genesis. This is because it is difficult to establish any co-genetic relationship between carbonatites and ultramafic lamprophyres. This suggests that more than one mantle melts are responsible for crystallization of these rocks. There are few geochemical characters observed in the studied rocks that may throw light on this aspect. Carbonatite samples perhaps show different geochemical nature and were not derived from a single melt. There is a possibility of fractionation of a primary carbonatite nephelinite melt, however, it is difficult to establish any fractionation trends between carbonatites and ultramafic lamprophyres, and therefore this possibility is not likely. Both viable options, the origin by liquid immiscibility or by direct melting of a carbonated mantle source, may explain genesis of this association, however this can only be settled by using isotopes and by knowing the ages of the different rock types. Nevertheless, the presence of carbonate ocelli in ultramafic lamprophyre samples supports liquid immiscibility process for the genesis of ultramafic lamprophyre and associated carbonatite. But, it is also true that few carbonatite emplacements are derived from different primary melts that could have directly originated from a carbonated mantle source.
A multi-stage veined mantle melting model for ultramafic lamprophyre magma production beneath an incipiently rifted cratonic area is suggested for the Aillik Bay area (Tappe et al. 2006) and other places such as along the borders of the Labrador Sea (Tappe et al. 2005). Srivastava et al. (2009) have also discussed genesis of aillikites from the Jharia area (Singhbhum craton, central India). Geochemical characteristics of Jharia aillikites suggest vein-plus-wall-rock melting model for their genesis (Foley 1992). Early stages of rifting, probably due to a plume, could have provided a venue for the melting of such vein-plus-wall-rock source. Foley (2008) also suggested similar mechanism for the genesis of ultramafic lamprophyres and other alkaline magmas during the early stages of cratonic rifting.

Mitchell and Tappe (2010) have suggested that carbonated ultramafic lamprophyre magmas, such as aillikites, may be parental to many carbonatite intrusions in areas of rifted cratonic lithosphere. This hypothesis is justified for aillikites reported from the North Atlantic craton (NAC). The model suggests that aillikites are formed from mixed source regions that involve phlogopiteand carbonate-rich veins within peridotite at the lithosphere-asthenosphere boundary and not from some hypothetical carbonate-melt derived at depth (Tappe et al. 2006, 2007). Furthermore, primitive ultramafic lamprophyre samples (which are very close to aillikitic compositions) from the Chitrangi area (CH22 and CH23) plot close to those melts that segregated significantly above the carbonatebearing solidus close to $5 \mathrm{GPa}$ in the Gudfinnsson and Presnall (2005) experiments, whereas other samples (both ultramafic lamprophyres and carbonatites) possibly show evidence of low-pressure differentiation processes (figure 4c); similar nature is also documented for the Aillik Bay aillikites (Tappe et al. 2006).

There are few regions, such as Labrador Sea, which are well-known for emplacement of different alkaline magmas in a rift setting. Such setting has been explained in terms of zones of persistent lithospheric weakness spatially controlling the magmatism (Larsen and Rex 1992) which is further supported by findings of alkaline rock associations at the conjugate Canadian margin (Digonnet et al. 2000; Tappe et al. 2004, 2006). This is discussed, in detail, by Tappe et al. (2007), who presented a tectonomagmatic model for a segment of the NAC close to the southern craton margin. This model explains how NAC was crosscut by the Labrador Sea that opened during the Early Cenozoic after extensive Mesozoic continental rifting and removal of cratonic mantle, which was followed at about 150 Ma by the cessation of ultrapotassic and potassic-to-carbonatitic magma production. 
They mentioned that at Aillik Bay, a sequence of olivine lamproites (1374.2 $\pm 4.2 \mathrm{Ma})$, aillikites/carbonatites (590-555 Ma), and nephelinites $(141.6 \pm 1.0 \mathrm{Ma})$ erupted through the southern NAC edge on the present day Labrador Sea margin. Probably similar tectonomagmatic situation was present at the studied area of Mahakoshal belt. Plume-like signature observed for the studied Chitrangi samples (figure 9) and also previously studied Paleoproterozoic mafic dykes (Srivastava 2012) could imply that plume played an important role in the crustal thinning and rifting of the Mahakoshal region. However, robust geochronology and radiogenic isotope data are required to confirm this model for the present studied area.

\section{Conclusions}

From the above discussion, observed field, petrological and geochemical features, it may be concluded that all the ultramafic lamprophyre (possibly aillikites) and carbonatites, emplaced within the Mahakoshal rift system, are not co-genetic; surely more than two melts derived from lithospheric mantle (well supported by high $\mathrm{Mg} \#$, and $\mathrm{Ni}$ and $\mathrm{Cr}$ and low HREE) were responsible for their genesis. The ultramafic lamprophyre and associated carbonatite are probably derived through liquid immiscibility of a melt produced from melting of a carbonated mantle. Presence of carbonate ocelli in ultramafic lamprophyre samples also corroborates this hypothesis. However, their derivation through vein-plus-wall-rock melting model cannot be discounted. In this case metasomatism also played an important role. Plume signature is also observed for the studied ultramafic lamprophyre and carbonatite samples and it is thought that early stages of rifting in the Mahakoshal region due to plume activity and lithospheric thinning provided suitable conditions for the genesis of ultramafic lamprophyre (aillikitic) and carbonatitic melts which ultimately crystallizes as dykes and plugs. Although it is difficult to say anything specific on the presence or absence of carbonated alkaline ultramafic magmatism during the Archaean, it is very clear that for the genesis of such melts a rift tectonic environment is vital. Rift tectonic environment essentially involved lithospheric extension, which may have resulted due to a plume.

\section{Acknowledgements}

The author is thankful to Council of Scientific and Industrial Research, New Delhi for the financial support through a Scheme 24 (0288)/06/EMRII). Author is grateful to Sebastian Tappe and
Steve Foley for their valuable suggestions for the improvement of the earlier version of manuscript. He is also grateful to two official reviewers (Jussi S Heinonen and an anonymous) and Talat Ahmad, the Handling Editor, for providing very comprehensive and constructive comments that helped much in improving the manuscript.

\section{References}

Acharyya S K 2001 Geodynamic setting of the Central Indian Tectonic Zone in central, eastern and northeastern India; Geol. Surv. India Spec. Publ. 64 17-35.

Acharyya S K and Roy A 2000 Tectonothermal history of the Central Indian Tectonic Zone and reactivation of major faults/shear zones; J. Geol. Soc. India 55 239-246.

Bailey D K 1993 Carbonate magmas; J. Geol. Soc. 150 637-651.

Baksi A K 2000 Search for a deep-mantle component in mafic lavas using Nb-Y-Zr plot; Canadian J. Earth Sci. 38 813-824.

Bell K 1998 Radiogenic isotopic constraints on relationships between carbonatites and associated silicate rocks - a brief review; J. Petrol. 39 1987-1996.

Bell K, Kjarsgaard B A and Simonetti A 1998 Carbonatiteinto the twenty-first century; J. Petrol. 39 1839-1845.

Blichert-Toft J, Arndt N T and Ludden J N 1996 Precambrian alkaline magmatism; Lithos 37 97-111.

Chaudhuri A and Basu A 1990 Nature of volcanism and related gold mineralisation at Suda, Sidhi District, Madhya Pradesh; Geol Surv. India Spec. Publ. 28 549-562.

Condie K C and Sinha A K 1996 Rare earth and other trace element mobility during mylonitization: A comparison of the Brevard and Hope Valley shear zones in the Appalachian Mountains, USA; J. Met. Geol. 14 213-226.

Dalton J A and Presnall D C 1998 Carbonatitic melts along the solidus of model lherzolite in the system $\mathrm{CaO}-\mathrm{MgO}-$ $\mathrm{Al}_{2} \mathrm{O}_{3}-\mathrm{SiO}_{2}-\mathrm{CO}_{2}$ from 3 to $7 \mathrm{GPa}$; Contrib. Mineral. Petrol. 131 123-135.

Digonnet S, Goulet N, Bourne J, Stevenson R and Archibald D 2000 Petrology of the Abloviak aillikite dykes, New Québec: Evidence for a Cambrian diamondiferous alkaline province in northeastern North America; Canadian J. Earth Sci. 37 517-533.

Evensen N M, Hamilton P J and O'Nion R K 1978 Rare earth abundances in chondritic meteorites; Geochim. Cosmochim. Acta 42 1199-1212.

Ferguson J and Currie K L 1971 Evidence of liquid immiscibility in alkaline ultrabasic dikes at Callander Bay, Ontario; J. Petrol. 12 561-585.

Fitton J G, Saunders A D, Norry M J, Hardarson B S and Taylor R N 1997 Thermal and chemical structure of the Iceland plume; Earth Planet Sci. Lett. 153 197-208.

Floyd P A and Winchester J A 1978 Identification and discrimination of altered and metamorphosed volcanic rocks using immobile elements; Chem. Geol. 21 291-306.

Foley S F 1984 Liquid immiscibility and melt segregation in alkaline lamprophyres from Labrador; Lithos $\mathbf{1 7}$ $127-137$.

Foley S F 1992 Vein-plus-wall-rock melting mechanisms in the lithosphere and the origin of potassic alkaline magmas; Lithos 28 435-438.

Foley S F 2008 Rejuvenation and erosion of the cratonic lithosphere; Nature Geosci. 1 503-510.

Frey F A, Green D H and Roy S D 1978 Integrated models of basalt petrogenesis: A study of quartz tholeiites 
to olivine melilitites from south eastern Australia utilizing geochemical and experimental petrological data; J. Petrol. 19 463-513.

Gale G H, Dabek L B and Fedikow M A F 1997 The application of rare earth element analyses in the exploration for volcanogenic massive sulfide type deposits; Explor. Min. Geol. 6 233-252.

Gittins J 1989 The origin and evolution of carbonatite magma; In: Carbonatite - Genesis and Evolution (ed.) Bell K (London: Unwin Hyman), pp. 580-600.

Gittins J and Harmer R E 2003 Myth and reality in the carbonatite-silicate rock "association"; Period. Mineral. 72 19-26.

Gudfinnsson G H and Presnall D C 2005 Continuous gradations among primary carbonatitic, kimberlitic, melilititic, basaltic, picritic, and komatiitic melts in equilibrium with garnet lherzolite at 3-8 GPa; J. Petrol. 46 1645-1659.

Hamilton D L, Freestone I, Dawson J B and Donaldson C H 1979 Origin of carbonatites by liquid immiscibility; Nature 279 52-54.

Harmer R E 1999 The petrogenetic association of carbonatite and alkaline magamatism: Constraints from the Spitskop Complex, South Africa; J. Petrol. 40 525-548.

Jain S C, Nair K K K and Yedekar D B 1995a Geology of the Son-Narmada-Tapti lineament zone in Central India; Geol. Surv. India Spec. Publ. 10 1-154.

Jain S C, Nair K K K and Yedekar D B 1995b Tectonic evolution of the Son-Narmada-Tapti lineament zone; Geol. Surv. India Spec. Publ. $10333-371$.

Jochum K P and Verma S P 1996 Extreme enrichment of $\mathrm{Sb}, \mathrm{Tl}$, and other trace elements in altered MORB; Chem. Geol. 130 289-299.

Kumar V 1993 Petrography and geochemistry of Jungel metavolcanics, Bijawar greenstone belt, Central India: A picritic basalt low K-andesite association; J. Geol. Soc. India 41 9-19.

Larsen L M and Rex D C 1992 A review of the $2500 \mathrm{Ma}$ span of alkaline-ultramafic, potassic and carbonatitic magmatism in West Greenland; Lithos 28 367-402.

Lefebvre N, Kopylova M and Kivi K 2005 Archaean calcalkaline lamprophyres of Wawa, Ontario, Canada: Unconventional diamondiferous volcaniclastic rocks; Precamb. Res. 138 57-87.

Le Maitre R W 2002 Igneous rocks: A classification and glossary of terms (Cambridge: Cambridge University Press), $236 \mathrm{p}$.

Le Roex A P and Lanyon R 1998 Isotope and trace element geochemistry of cretaceous damaraland lamprophyres and carbonatites, northwestern Namibia: Evidence for plumelithosphere interactions; J. Petrol. 39 1117-1146.

McDonough W F and Sun S-S 1995 The composition of the Earth; Chem. Geol. 120 223-253.

McDonough W F, Sun S-S, Ringwood A E, Jagoutz E and Hofmann A W $1992 \mathrm{~K}, \mathrm{Rb}$ and Cs in the earth and moon and the evolution of the earth's mantle; Geochim. Cosmochim. Acta 56 1001-1012.

Meschede M 1986 A method of discrimination between different types of mid-ocean ridge basalts and continental tholeiites with the Nb-Zr-Y diagram; Chem. Geol. 56 207-218.

Mitchell R H 2005 Carbonatites and carbonatites and carbonatites; Canadian Mineral 43 2049-2068.

Mitchell R and Tappe S 2010 Discussion of "Kimberlites and aillikites as probes of the continental lithospheric mantle", by Francis D, Patterson M (Lithos 109 72-80), Lithos $115288-292$.

Mitchell R H, Scott-Smith B H and Larsen L M 1999 Mineralogy of ultramafic dikes from the Sarfartoq, Sisimiut and Maniitsoq areas, West Greenland; In: Proc VII Intern
Kimb Conf. (eds) Gurney J J, Gurney J L, Pascoe M D and Richardson S H (Cape Town: Red Roof Design), pp. $574-583$.

Naganjaneyulu K and Santosh M 2010 The Central India Tectonic Zone: A geophysical perspective on continental amalgamation along a Mesoproterozoic suture; Gondwana Res. 18 547-564.

Nair K K K, Jain S C and Yedekar D B 1995 Stratigraphy, structure and geochemistry of the mahakoshal greenstone belt; Geol. Surv. India Memoir 31 403-432.

Naqvi S M and Rogers J J W 1987 Precambrian Geology of India (New York: Oxford University Press), 223p.

Nielsen T F D, Jensen S M, Secher K and Sand K K 2009 Distribution of kimberlite and aillikite in the Diamond Province of southern West Greenland: A regional perspective based on groundmass mineral chemistry and bulk compositions; Lithos 112S 358-371.

Pearce J A and Cann J R 1973 Tectonic setting of basic volcanic rocks determined using trace element analyses; Earth Planet Sci. Lett. 19 290-300.

Pearce J A and Norry M J 1979 Petrogenetic implications of Ti, Zr, Y and Nb variations in volcanic rocks; Contrib. Mineral. Petrol. $6933-47$.

Raza M, Khan A and Khan M S 2009 Origin of late Paleoproterozoic Great Vindhyan basin of North Indian shield: Geochemical evidence from mafic volcanic rocks; J. Asian Earth Sci. 134 716-730.

Rock N M S 1986 The nature and origin of ultramafic lamprophyres: Alnöites and allied rocks; J. Petrol. 27 155-196.

Rock N M S 1987 The nature and origin of lamprophyres: An overview; In: Alkaline igneous rocks (eds) Fitton J G and Upton B G; J. Geol. Soc. London Spec. Publ. 30 191-226.

Rock N M S 1991 Lamprophyres (Glasgow: Blackie and Sons Ltd.), 285p.

Rollinson H R 1993 Using geochemical data: Evaluation, presentation, interpretation (Essex: Longman), 352p.

Roy A and Bandyopadhyay B K 1988 Tectonic significance of ultramafic and associated rocks near Tal in the Bijawar belt, Sidhi district, Madhya Pradesh; J. Geol. Soc. India 32 397-410.

Roy A and Bandyopadhyay B K 1989 Geology and geochemistry of metabasalts near Sleemanabad in the Proterozoic Mahakoshal belt of Central India; Indian Minerals 43 303-324.

Roy A and Bandyopadhyay B K 1990 Tectonic and structural pattern of the Mahakoshal belt of central India: A discussion; Geol. Surv. India Spec. Publ. 28 226-240.

Roy A and Chakraborty K 2008 Precambrian maficultramafic magmatism in Central Indian Suture Zone; J. Geol. Soc. India 72 123-140.

Roy A and Hanuma Prasad M 2003 Tectonothermal events in Central Indian Tectonic Zone (CITZ) and its implications in Rodinian crustal assembly; J. Asian Earth Sci. 22 115-129.

Roy A, Ramachandra H M and Bandyopadhyay B K 2000 Supracrustal belts and their significance in the crustal evolution of central India; Geol. Surv. India Spec. Publ. 55 361-380.

Rudnick R L and Fountain D M 1995 Nature and composition of the continental crust: A lower crustal perspective; Rev. Geophys. 33 267-309.

Seewald J S and Seyfried W E 1990 The effect of temperature on metal mobility in sub-seafloor hydrothermal systems: Constraints from basalt alteration experiments; Earth Planet Sci. Lett. 101 388-403.

Srivastava R K 2012 Petrological and geochemical studies of paleoproterozoic mafic dykes from the Chitrangi Region, Mahakoshal Supracrustal Belt, Central Indian Tectonic 
Zone: Petrogenetic and tectonic significance; J. Geol. Soc. India $80369-381$.

Srivastava R K and Chalapathi Rao N V 2007 Petrology, geochemistry and tectonic significance of Paleoproterozoic alkaline lamprophyres from the Jungel valley, Mahakoshal supracrustal belt, central India; Mineral. Petrol. 89 189-215.

Srivastava R K, Heaman L M, Sinha A K and Shihua S 2005 Emplacement age and isotope geochemistry of Sung Valley Alkaline-Carbonatite Complex, Shillong Plateau, Northeastern India: Implications for primary carbonate melt and genesis of the associated silicate rocks; Lithos $8133-54$.

Srivastava R K, Chalapathi Rao N V and Sinha A K 2009 Cretaceous alkaline intrusives with affinities to aillikites from the Jharia area: Magmatic expression of metasomatically veined and thinned lithospheric mantle beneath the Singhbhum Craton, Eastern India; Lithos 112S 407-418.

Tappe S, Jenner G A, Foley S F, Heaman L M, Besserer D, Kjarsgaard B A and Ryan A B 2004 Torngat ultramafic lamprophyres and their relation to the North Atlantic Alkaline Province; Lithos 76 491-518.

Tappe S, Foley S F, Jenner G A and Kjarsgaard B A 2005 Integrating ultramafic lamprophyres into the IUGS classification of igneous rocks: Rational and implications; J. Petrol. 46 1893-1900.

Tappe S, Foley S F, Jenner G A, Heaman L M, Kjarsgaard B A, Romer R L, Stracke A, Joyce N and Hoefs J 2006 Genesis of ultramafic lamprophyres and carbonatites at Aillik Bay, Labrador: A consequence of incipient lithospheric thinning beneath the North Atlantic craton; J. Petrol. 47 1261-1315.

Tappe S, Foley S F, Stracke A, Romer R L, Kjarsgaard B A, Heaman L M and Joyce N 2007 Craton reactivation on the Labrador Sea margins: 40Ar/39Ar age and $\mathrm{Sr}-\mathrm{Nd}-$ $\mathrm{Hf}-\mathrm{Pb}$ isotope constraints from alkaline and carbonatite intrusive; Earth Planet Sci. Lett. 256 433-454.

Tappe S, Pearson D G, Nowell G, Nielsen T, Milstead P and Muehlenbachs K 2011 A fresh isotopic look at Greenland kimberlites: Cratonic mantle lithosphere imprint on deep source signal; Earth Planet Sci. Lett. 305 235-248.

Thakur K S and Shukla R S 1990 Geochemistry of early Proterozoic metabasites and associated copper mineralization in Karaudiya area in Mahakoshal rift basin, Shahdol district, Madhya Pradesh; In: Precambrians Central India; Geol. Surv. India Spec. Publ. 28 512-526.

Verma S P 1992 Seawater alteration effects on REE, K, Rb, $\mathrm{Cs}, \mathrm{Sr}, \mathrm{U}, \mathrm{Th}, \mathrm{Pb}$, and $\mathrm{Sr}-\mathrm{Nd}-\mathrm{Pb}$ isotope systematic of mid-ocean ridge basalts; Geochem. J. 26 159-177.

Verma S P, Torres-Alvarado I S and Sitelo-Rodriguez Z T 2002 SINCLAS: Standard igneous norm and volcanic rock classification system; Comp. Geosci. 28 711-715.

Vichi G, Stoppa F and Wall F 2005 The carbonate fraction in carbonatitic Italian lamprophyres; Lithos $\mathbf{8 5}$ $154-170$.

Winchester J A and Floyd P A 1976 Geochemical magma type discrimination, application to altered and metamorphosed basic igneous rock; Earth Planet Sci. Lett. 28 459-469.

Wood D A 1980 The application of a Th-Hf-Ta diagram to problems of tectonomagmatic classification and to establishing the nature of crustal contamination of basaltic lavas of the British Tertiary volcanic province; Earth Planet Sci. Lett. 50 11-30.

Woolley A R 2003 Igneous silicate rocks associated with carbonatites: Their diversity, relative abundences and implications for carbonatite genesis; Period. Mineral. 72 9-17. 